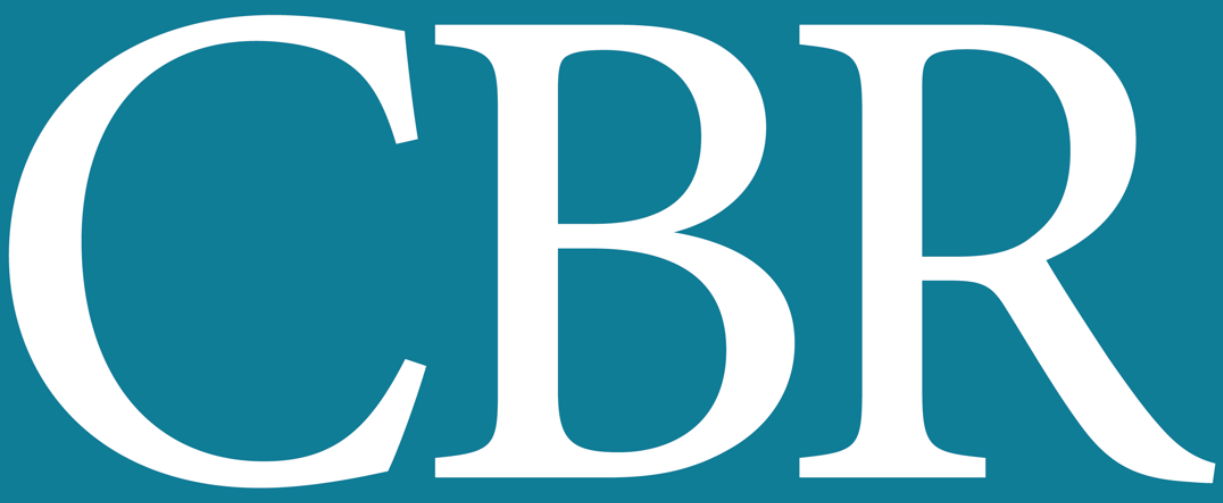

INTERNATIONAL JOURNAL OF CANCER AND BIOMEDICAL RESEARCH

https://jcbr.journals.ekb.eg

Editor-in-chief

Prof. Mohamed Labib Salem, PhD

Comparing productivity and tolerance of melanin-producing Streptomyces

longisporoflavus and Aspergillus niger under biosorption capacity

Eman H.F. Abd El-Zaher, Nanis G. Allam and Asmaa E. Allam 


\section{Welcome letter from Editor-in-Chief}

Welcome to the Int J Cancer and Biomedical Research (IJCBR)!

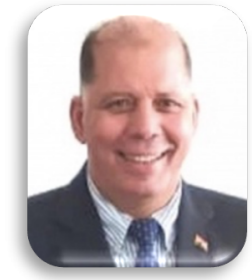

It is with great pleasure that I write this editorial to welcome you to the IJCBR. This journal provides a platform for publication of original and reviews research articles, short communications, letter to editor, thesis abstract, conference report, and case studies. These types of publication are directed at the interface of the fields of cancer and biomedical research.

The IJCBR relies on a distinguished expert of the Advisory and Editorial Board Members from the top international league covering in depth the related topics. They timely review all manuscripts and maintain highest standards of quality and scientific methodology and ethical concepts. Meanwhile, we take all possible means to keep the time of the publication process as short as possible.

I take this chance to welcome your contributions to the IJCBR and have every expectation that it will soon become one of the most respected journals in both the fields of cancer and biomedical research.

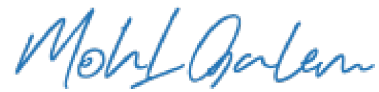

Mohamed L. Salem,

Editor in Chief 


\title{
Comparing productivity and tolerance of melanin-producing Streptomyces longisporoflavus and Aspergillus niger under biosorption capacity
}

\author{
Eman H.F. Abd El-Zaher, Nanis G. Allam and Asmaa E. Allam \\ Botany and Microbiology Department, Faculty of Science, Tanta University, Tanta, Egypt
}

\section{ABSTRACT}

Background: Melanin (Mel) is a naturally occurring pigment made by some microorganisms. Streptomyces $\mathrm{sp}$ and Aspergillus niger are capable of producing a high quantity of brown (Mel1) - black (Mel2) intercellular Mel pigments. Aim: To compare between melanin-producing Streptomyces $\mathrm{sp}$ and Aspergillus niger productive efficiency and tolerance against lead and cadmium ions stress was investigated. Materials and Methods: The tested strains were identified by molecular characterizations (16S rRNA \& 18S rRNA) gene sequence, Mel1 of $S$. longisporoflavus NR043926 and Mel2 of A. niger MT355517 were extracted and purified from the dried microbial biomass. Physicochemical characterizations of extracted Mel pigments were compared with standard melanin based on infrared (IR) analysis. The productive efficiency and tolerance under absorption capacity of the selected strains against lead and cadmium ions were identified as the minimum inhibitory concentration (MICs) of each metal ions. Results: The production of Mel pigments and growth of two selected strains were decreased gradually by increasing the concentration of cadmium or lead from (10-750 ppm). Transmission electron microscopic examination showed heavy metals binding occurred on the surface of the microorganism cells, uptake or precipitation inside the melanized inner cell wall, finally vacuoles and microbial cells damage. Conclusion: $A$. niger can resist cadmium and lead ions more than $S$. longisporoflavus, Mel2 had a high protective function toward the stress of the heavy metal in comparison to Mel1.

Keywords: Aspergillus niger, Cadmium, Lead, Melanin, and Streptomyces longisporoflavı

Editor-in-Chief: Prof. M.L. Salem, PhD - Article DOI: 10.21608/jcbr.2020.36127.1056

\section{ARTICLE INFO}

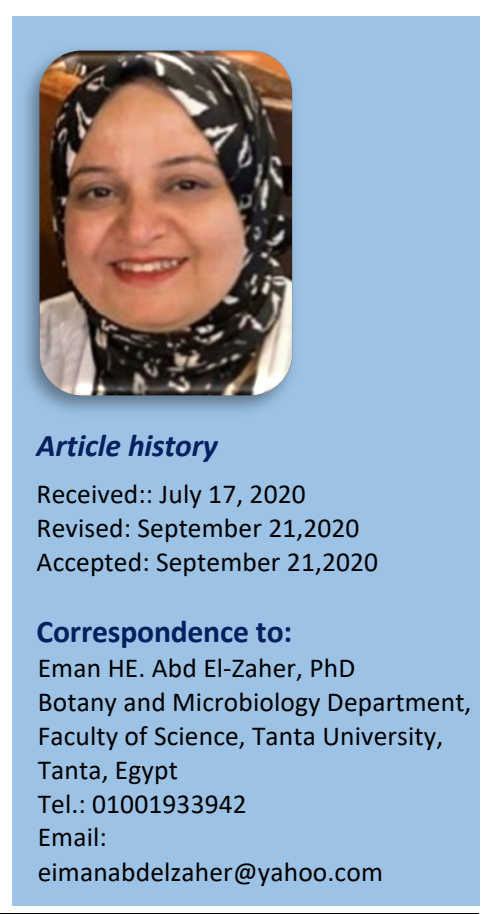

\section{INTRODUCTION}

Melanin (Mel) pigments are hydrophobic and negatively charged high molecular weight pigments. They are commonly found in animals, plants, fungi and bacteria. In fungi and bacteria, melanin pigments are found in their cell wall or they exist as extracellular polymers. Mel is a polymeric phenolic compound which is categorized into two major classes based on its chemical structures and molecular precursors: eumelanin (dark brown-black) and pheomelanin (orange-red). All eumelanin and pheomelanin are strongly cross-linking, complex biopolymers (Herrera et al., 2019). Tyrosinase in some microorganisms is the enzyme involved in the key step in the formation of melanin that helps in the conversion of tyrosine to 3, 4-dihydroxy Lphenylalanine (L-DOPA) by a one-step oxidation reaction under batch culture. (Ali and Haq, 2010). The biosynthesis of $1,3,6,8-$ tetrahydroxy naphthalene (DHN) melanin is converted in succession to scylatone, vermolone, and $\mathrm{DHN}$ are well understood. (Martinez et al., 2000).

It has been reported that Klebsiella sp bacteria could produce Mel pigment in the presence of L-tyrosine. Spissiomyces endophytica strain SDBR-CMU319, was able to produce a brownblack pigment in the mycelia. Mel production and characterization have been reported also from the genus Spissiomyces (Shrishailnath et al. 2010; Suwannarach et al., 2019). Mel is an amorphous, dark-colored pigment, insoluble in the most solvents, bleaching by oxidizing agents 
$\left(\mathrm{H}_{2} \mathrm{O}_{2}\right)$, and soluble in alkali and phenols (Krysciak, 1985). Pihet et al. (2009) reported that melanin deposition protects the pigmented cell against biophysical stress of resonancestabilized cyclic subunits, heavy metals stress, oxidative agents, ultraviolet rays, and skin cancer. Mel could protect microorganisms including fungi and bacteria, from stresses such as sun-borne UV radiation and reactive oxygen species. Mel also protects microorganisms against high temperatures, chemical stresses like heavy metals and oxidizing agents (Hamilton \& Gomez, 2002). Mel pigment can bind to heavy metals, which may influence the growth of microorganisms and production of Mel pigment (Pointing et al., 2000). Cadmium and lead removal by microbial biomass are a rapid process by which the bulk of the removal occurs during the first few minutes of contact between the metal solution and the biomass (Panes et al., 2012).

Joo and Hussein (2012) investigated the tolerance of some resistant fungal strains from soils polluted with heavy metals by MIC depending on the fungal species as the MIC of $\mathrm{Cd}$ for Aspergillus niger KNU3 and Penicillium funiculosum KNU4 was 400 ppm for each, while the other tolerant species e.g. Penicillium sp. and yeasts recorded MICs ranged from 200-300 ppm of the same heavy metal. Shiguo Chen et al., 2009 investigated the absorption of cadmium ( $\mathrm{Cd}$ ) and lead $(\mathrm{Pb})$ by squid Mel. Different functional groups are responsible for their absorption within Mel. Infra-red evaluation of metal ion-enriched squid melanin showed phenolic hydroxyl, carboxyl, and amine groups to be the likely functional groups responsible for metal binding. Previous studies have clarified the mechanisms responsible for biosorption, which can be one or a combination of ion exchange, teinting, coordination, absorption, electrostatic interaction, chelation and micro precipitation (Vegliò and Beolchini, 1997; Volesky and Schiewer, 1999). Cd and Pb elimination by microbial biomass are a rapid process in which the bulk of the removal of metal solution and biomass occur within the first few minutes of touch (Pardo et al., 2003; Komy et al., 2006). The biosorption capacity of live, autoclaved and dried biomass of Yarrowia lipolytica AUMC 9256 for cadmium (Cd(II)) to produce cadmium nanoparticles was determined by UV-Visible spectroscopy measurements and transmission electron microscopy examinations. Moreover, to identify the possible mechanisms of $\mathrm{Cd}$ (II) uptake. The potential implementation of dried $Y$. lipolytica biosorbent for heavy metal removal from different water samples was successfully accomplished using the multistage microcolumn technique. Accordingly, $Y$. lipolytica AUMC 9256 can be considered as a very promising potential to bioremediate $\mathrm{Cd}(\mathrm{II})$ ions (Manal, 2019).

The current study aimed to compare between Streptomyces sp and Aspergillus niger in producing high quantity of brown (Mel1) - black (Mel2) intercellular Mel pigments. Detecion the productive efficiency and tolerance under biosorption capacity of these strains against lead acetate and cadmium chloride activity. Identify the location of heavy metal particles within the melanized microbial cells in control and treated cultures under TEM examination.

\section{MATERIALS AND METHODS Microorganisms}

Streptomyces longisporoflavus NR043926 and Aspergillus niger MT355517 were identifed in 2015 by molecular characterizations (16S rRNA \& $18 \mathrm{~S}$ rRNA) gene sequences in GATC Company using $A B I$ 3730xI DNA sequence using forward and reverse primers (Sigma Scientific Services Co., Cairo, Egypt).

\section{Chemicals and reagents}

Dimethyl Sulphoxide (DMSO), was purchased from El-Gomhoria Company, (Tanta, Egypt). Cadmium chloride, lead acetate powder and other chemicals were purchased from Sigma Company (Cairo, Egypt).

\section{Molecular identification of melanin-producing Streptomyces sp.}

The 165 rDNA of bacteria was amplified and prepared by $P C R$ using universal primer $9 F\left(5^{\prime}\right.$ AGA GTT TGA TCC TGG CTC AG-3') and 1541R (5'- GGT TAC CTT GTT ACG ACT $-3^{\prime}$ ). Thermal cycling conditions were as follows: DNA denaturation at $98^{\circ} \mathrm{C}$ for 3 min followed by 30 cycles at $94{ }^{\circ} \mathrm{C}$ for $1 \mathrm{~min}$, annealing of the primers at $52^{\circ} \mathrm{C}$ for $1 \mathrm{~min}$, and then extension at 
$72{ }^{\circ} \mathrm{C}$ for $5 \mathrm{~min}$. The reaction mixture was held for $5 \mathrm{~min}$ at $72{ }^{\circ} \mathrm{C}$ and then cooled to $4{ }^{\circ} \mathrm{C}$. Sequencing of the PCR product was carried out by using an automated sequencer (Macrogen Inc., Seoul, Korea) and the same primers as above for sequence determination. The sequence was compared for similarity with the reference species of bacteria contained in genomic database banks, using the NCBI Blast. A phylogenetic tree based on 16S rRNA gene sequence was constructed with the neighborjoining method in MEGA version 4 software (Singh et al., 2012).

\section{Molecular identification of Aspergillus niger by $18 S$ rRNA gene sequence.}

The mycelium of Aspergillus niger was scratched off from the surface of Czapek's dox media. The fresh mycelia (50 mg) was ground in liquid nitrogen using a mortar and pestle. DNA was extracted from the powdered tissue using genomic plant DNA extraction Mini Kit according to the manufacturer's instructions. The eluted DNA was stored at $-20^{\circ} \mathrm{C}$ (White and Burn, 1990).

\section{Polymerase chain reaction (PCR) condition}

In automated thermal cycler, an amplification of the internal transcribed spacer (ITS) area was carried out (C1000 ${ }^{\mathrm{TM}}$ Thermal Cycler, Bio-RAD) using ITS4 (5`-TCCTCCGCTTATTGATATGC-3') and ITS5(5'-GGA AGT AAA AGT CGT AACAAGG$\left.3^{\prime}\right)$ primers. 35 cycles of $94^{\circ} \mathrm{C}$ for $30 \mathrm{~s}, 51{ }^{\circ} \mathrm{C}$ for $1 \mathrm{~min}, 72^{\circ} \mathrm{C}$ for $1.5 \mathrm{~min}$, and a final extension at $72^{\circ} \mathrm{C}$ for $3 \mathrm{~min} .1 \mu \mathrm{l}$ of $25 \mathrm{ng}$ nucleic acid, $1 \mu \mathrm{l}$ of each primer $(10 \mathrm{pmol}), 12.5 \mu \mathrm{l}$ of $\mathrm{GoTag}^{\circledR}$ colorless Master Mix (Promega Corporation, USA) and $9.5 \mu \mathrm{l}$ of nuclease-free water (Promega). $15 \mu \mathrm{l}$ of all PCR products were assessed by using electrophoresis through $1 \%$ agarose gel, with ethidium bromide staining and visualization of DNA bands were made by using a UV transilluminator (Sigma Scientific Services Co., Cairo, Egypt).

\section{Extraction of melanin pigment}

Extraction of melanin pigment (Mel1) Streptomyces sp was grown on starch- nitrate medium at ( $\mathrm{pH} 7.0)$, Petri dishes were prepared and inoculated each with a loop of bacteria. The inoculated Petri dishes were incubated for (7 days at $30^{\circ} \mathrm{C}$ ). Disks ( $10 \mathrm{~mm}$ diameters) were cut from the margin of the colonies, boiled for $1 \mathrm{~min}$ in $5 \mathrm{ml}$ distilled water and centrifuged for $15 \mathrm{~min}$ at $(5,000 \mathrm{rpm})$. After washing and centrifugation, the pigment was extracted by autoclaving the pellets for $\left(20 \mathrm{~min}\right.$ at $\left.120^{\circ} \mathrm{C}\right)$. The pellets were dissolved in $(3 \mathrm{ml}$ of $1 \mathrm{M} \mathrm{NaOH})$. The alkaline extracted melanin was acidified to $(\mathrm{pH}$ 2.0) with concentrated $\mathrm{HCl}$ for melanin precipitation. The precipitated melanin was washed in 3 changes with distilled water and dried overnight at $\left(20^{\circ} \mathrm{C}\right)$ in a dry atmosphere. Then, the extracted pigment was further purified by acid hydrolysis $(5 \mathrm{~m} 1$ of $7.0 \mathrm{M} \mathrm{HCl})$ in a sealed glass vial for $\left(2 \mathrm{~h}\right.$ at $\left.100^{\circ} \mathrm{C}\right)$. The precipitated melanin was washed three times with distilled water and dried overnight at $20^{\circ} \mathrm{C}$ in a dry atmosphere. The precipitated melanin was further purified by acid hydrolysis $(5 \mathrm{ml}$ of 7 $\mathrm{N} \mathrm{HC} 1)$ in sealed glass vials for $\left(2 \mathrm{~h}\right.$ at $\left.100^{\circ} \mathrm{C}\right)$ according to Gadd (1988).

Extraction of melanin pigment (Mel2) Aspergillus niger was grown on sabouraud's liquid medium at ( $\mathrm{pH} 7.0$ for 10 days at $\left.30^{\circ} \mathrm{C}\right)$. Upon centrifugation, at the end of the incubation cycle (for $20 \mathrm{~min}$ at $8000 \mathrm{rpm}$ ). The precipitate obtained to remove carbohydrates and proteins was purified by acid hydrolysis using $6.0 \mathrm{M} \mathrm{HCl}$ at $100{ }^{\circ} \mathrm{C}$ for $2 \mathrm{~h}$. The precipitate melanin washed distilled $\mathrm{H}_{2} \mathrm{O}$, after washing it was dried over anhydrous $\mathrm{Na}_{2} \mathrm{SO}_{4}$, then dissolved in $1 \mathrm{M} \mathrm{NaOH}$ and centrifugation at $4000 \mathrm{rpm}$ for $15 \mathrm{~min}$ for TLC separation, infrared spectra analysis and using authentic melanin as reference according to (Rowley and Pint, 1972) and (Sava, 2001).

Preparation of standard melanin Standard melanin was purchased from Sigma Company (Cairo, Egypt). Standard melanin solution was prepared by dissolving $0.05 \mathrm{~g}$ of melanin in $2 \mathrm{ml}$ of $1.0 \mathrm{M} \mathrm{NaOH}$.

Physicochemical properties of Mel extracted from Streptomyces longisporoflavus NR043826 (Mel1) and Aspergillus niger MT355517 (Mel2) According to Thomas (1955) and Ellis and Griffiths (1974), the isolated melanin pigments from each strain were tested for several physical and chemical characteristics including color, solubility, solubility in different organic solvents, polyphenol test, $\mathrm{FeCl}_{3}(1 \% \mathrm{w} / \mathrm{v})$, precipitation in $3.0 \mathrm{~N}-\mathrm{HC} 1$ and solubility in $1.0 \mathrm{M}$ 
$\mathrm{KOH}\left(100^{\circ} \mathrm{C}\right.$ for $\left.2 \mathrm{~h}\right)$, and was compared with the standard melanin.

\section{Infrared (IR) spectrum of melanin}

IR spectrum of the extracted Mel pigments was obtained using spectrophotometer PerkinElmer1430 (Micro Analytical Center, Faculty of Science, Cairo University, Cairo, Egypt). Small discs were made from the mixture of about 1.0 $\mathrm{mg}$ of the tested materials and $300 \mathrm{mg}$ of pure $\mathrm{KBr}$, followed by pressing into a disc and used for determination of the infrared spectra. The measurements were carried out at infra-red spectra between 400 and $4000 \mathrm{~nm}$ (SherborokCox et al., 1984). In vitro, protective efficiency and tolerance under biosorption capacity of $S$. longisporoflavus NR043826 and A. niger MT355517 against cadmium and lead ions stress.

\section{Heavy metal tolerance}

The two tested strains were checked for their tolerance to heavy metal against cadmium chloride and lead acetate. Aqueous metal solutions were prepared in dist. $\mathrm{H}_{2} \mathrm{O}$ and added to starch nitrate media for $S$. longisporoflavus NR043826 and Sabouraud's media for A. niger MT355517 to obtain a final concentration 10 ppm in each case. Each strain was cultured onto triplicate of their media with $10 \mathrm{ppm}$ of cadmium or lead, streaked on the surface of media then incubated for $24 \mathrm{~h}$ at $37{ }^{\circ} \mathrm{C}$ for the bacterium (Mrvcic et al., 2009), and 7 days at 28 ${ }^{\circ} \mathrm{C}$ for the fungus.

\section{Determination of MICs of $S$. longisporoflavus NR043826 and A. niger MT355517, Mel1 and Mel2 production against cadmium and lead stress}

The MICs of the tested strains on growth and Mel production were detected against cadmium and lead ions, separately. The concentration of each metal solution was gradually increased (10 - 750 ppm). Two microbial strains were inoculated on the surface of tested strain media which supplemented with each concentration of metal solutions. The flasks were incubated at $37{ }^{\circ} \mathrm{C}$ for $24 \mathrm{~h}$. The concentration of metal was increased till MICs was achieved as visualized by the cessation of melanin production and organism's growth according to Washington and Sutter (1980); Joo and Hussein (2012).

\section{Transmission electron microscopy (TEM) examination}

The control and treated cultures were examined by TEM in order to identify the location of lead particles within the microbial cells. Solution of 5 $\mathrm{mg} / \mathrm{L}$ of lead acetate was prepared. A weighed amount of each tested strain cell pellets was suspended in a lead solution with a final concentration of $1.0 \mathrm{~g} / \mathrm{L}$ of microbial strains. The $\mathrm{pH}$ of the suspension was adjusted to 6.0, and the samples were incubated for $1 \mathrm{~h}$ at $28^{\circ} \mathrm{C}$ followed by centrifugation at 5,000 rpm for 20 min. Control was conducted in the lead-free distilled water. The location of lead particles $(250,500$ and $750 \mathrm{ppm})$ within each strain cells of treated cultures was identified according to Halttunen et al. (2008). After fixation and dehydration, samples were embedded in Araldite 502 resin. The plastic molds were cut at $805 \mathrm{~nm}$ thicknesses in Ultra cut ultramicrotome, and then they were stained with $1 \%$ toluidine blue. Photography was made using JEOL, JEM-100 SX electron microscope (Japan) in Faculty of Medicine, Tanta University.

\section{Statistical analysis}

Statistical analysis was carried out If there a significant difference between means, Tukey post hoc comparisons among different groups were performed. For all statistical tests $P$ values $\leq 0.05$ was considered to be statistically significant. Data and statistical analysis were performed using Excel 2016 (Microsoft Corporation, USA), SPSS statistical version 23 software package (SPSS Inc., USA) and Minitab version 18 (SAS, 1985).

\section{RESULTS}

\section{Molecular identification of Streptomyces sp.}

Using 16S rDNA sequence, we compared the tested nucleotide sequences with the members of actinomycetes. This clearly showed that the tested Streptomyces sp strain revealed 99\% similarity with other strains of Streptomyces sp accessed in GenBank. The strain identified as $S$. longisporoflavus NRRL ISP-5165 (Accession NO: NR043826) as shown in Figure 1. Other strains belong to section Streptomyces sp exhibited slightly similarity (85\%) to our tested strain. 


\section{Molecular identification of Aspergillus niger}

Using the genotypic identification 18S rDNA sequence, comparison of the tested nucleotide sequences with the members of Aspergillus sp strain in GenBank revealed $99.9 \%$ similarity with other strains of Aspergillus niger (Accession NO: MT355517) as shown in Figure 2. The fungal strain belongs to section $A$. niger such as Aspergillus niger KY825168 and Aspergillus niger MH748223 exhibited slightly similarity (99.8\%).

\section{Physicochemical properties of Mel1 and Mel2}

Properties of the extracted Mel pigments were illustrated in Table 1 . They were insoluble in water and organic solvents such as (acetone, chloroform and ethanol) or such solvent mixture, were acidified by concentrated $\mathrm{HCl}$ to $\mathrm{pH} 2.2$, were decolorated by oxidizing agents $\left(\mathrm{H}_{2} \mathrm{O}_{2}\right.$ and $\left.\mathrm{NaOC} 1\right)$, gave positive reactions to polyphenol compounds and produced 1 percent $(w / v)$ flocculent brown precipitates with $\mathrm{FeC}_{3}$.

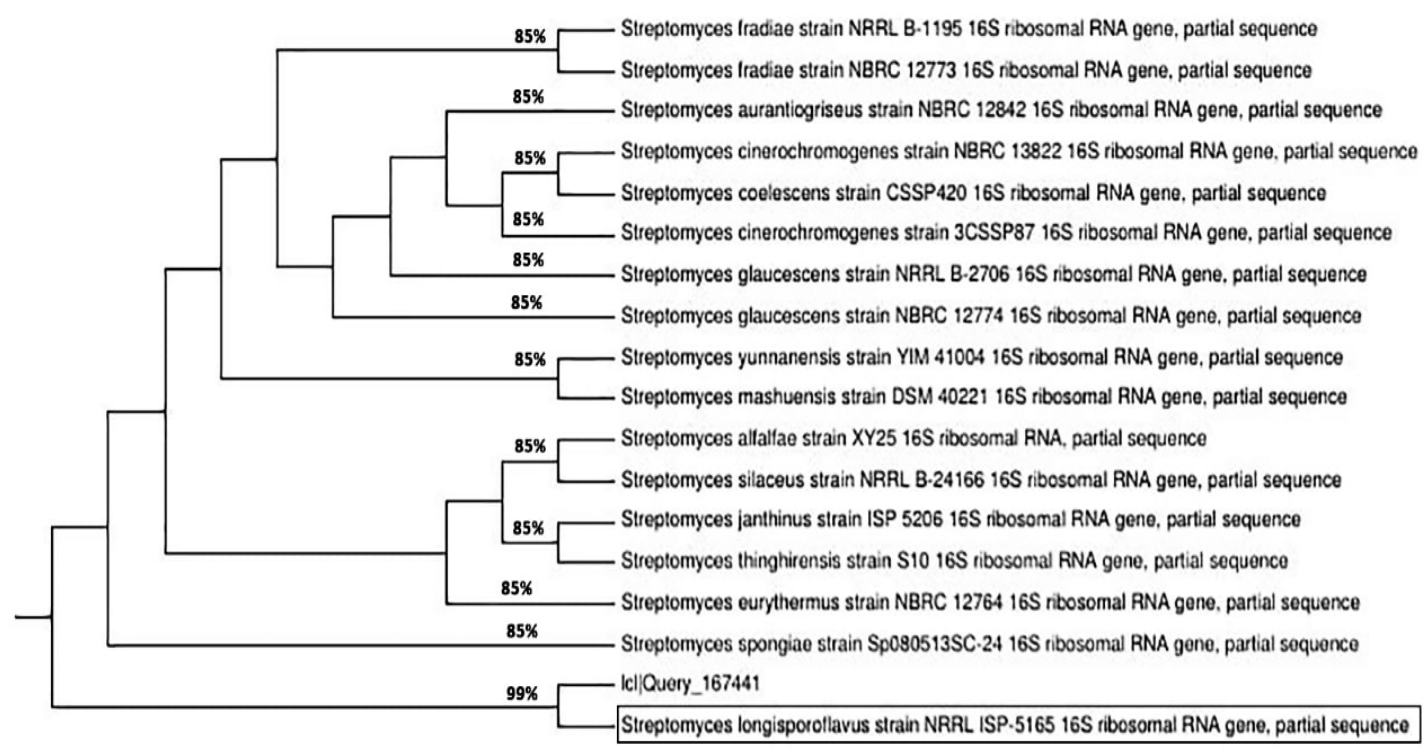

Figure 1. Phylogenetic analysis of S. longisporoflavus based on complete sequencing of 16S rDNA.

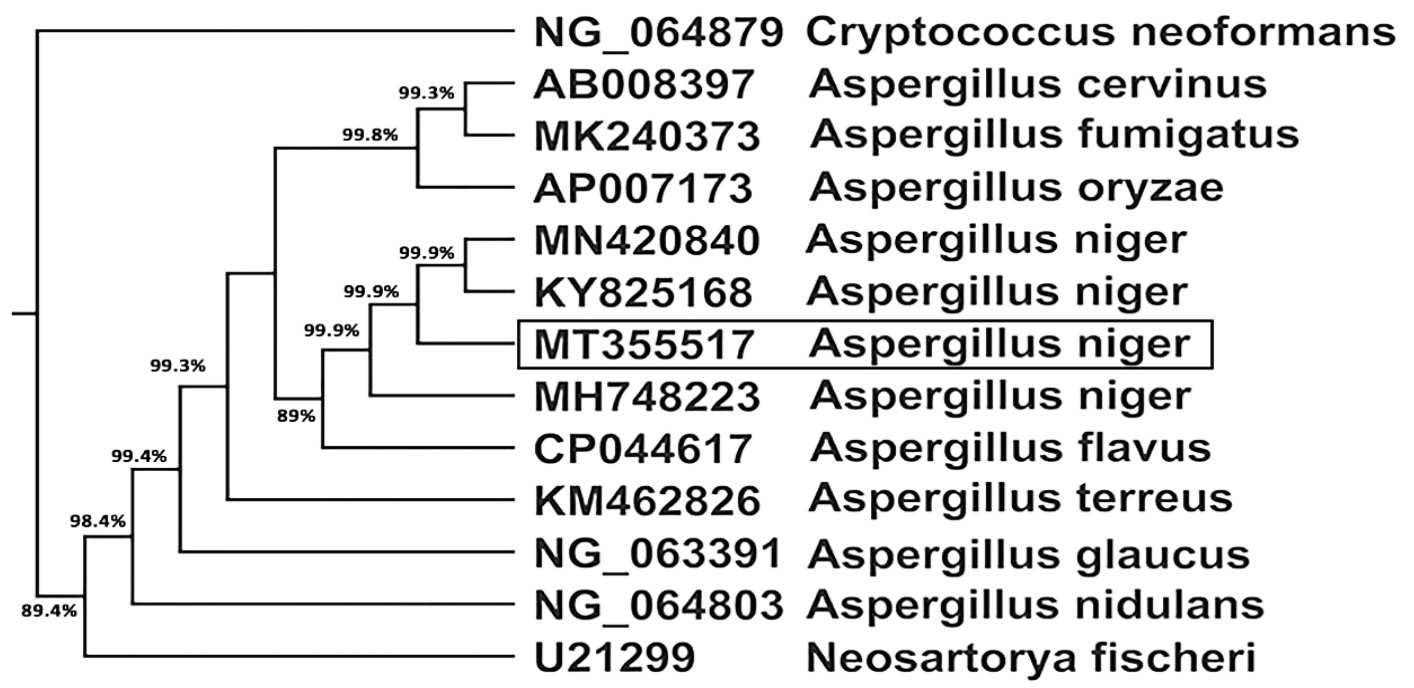

Figure 2. Phylogenetic analysis of A. niger MT355517 based on complete sequencing of $18 \mathrm{~S}$ rDNA. 


\section{Infrared (IR) analysis}

The precipitated Mel pigments have peaks with wave numbers appeared at $3412.42 \mathrm{~cm}^{-1}$, $2924.1452 \mathrm{~cm}^{-1}, 2860.88 \mathrm{~cm}^{-1}, 2367.19 \mathrm{~cm}^{-1}$, $1746.23 \mathrm{~cm}^{-1}, 1641.13 \mathrm{~cm}^{-1}, 1455.03 \mathrm{~cm}^{-1}$, $866.846 \mathrm{~cm}^{-1}, 708.712 \mathrm{~cm}^{-1}$ and $606.503 \mathrm{~cm}^{-1}$. (Figure 3a) show the extracted Mel1. Whereas the extracted Mel2 recoded peaks at wave numbers $3404.71 \mathrm{~cm}^{-1}, 2924.52 \mathrm{~cm}^{-1}, 2859.92$ $\mathrm{cm}^{-1}, 2631.39 \mathrm{~cm}^{-1}, 1739.48 \mathrm{~cm}^{-1}, 1635.34 \mathrm{~cm}^{-1}$, $1445.39 \mathrm{~cm}^{-1}, 884.202 \mathrm{~cm}^{-1}, 785.85 \mathrm{~cm}^{-1}$ and $606 \mathrm{~cm}^{-1}$ (Figure 3b).

The wave number occurred can be ascribed to the following: (3412.42 $\mathrm{cm}^{-1}$ and $2924.1452 \mathrm{~cm}^{-}$ $\left.{ }^{1}\right)$ and $\left(3404.71 \mathrm{~cm}^{-1}\right.$ and $\left.2924.52 \mathrm{~cm}^{-1}\right)$ attributed to $\mathrm{OH}$ and $\mathrm{NH}$ bonds. $(2860.88 \mathrm{~cm}$ ${ }^{1}$ and $\left.2367.19 \mathrm{~cm}^{-1}\right)$ and $\left(2859.92 \mathrm{~cm}^{-1}\right.$, and $2631.39 \mathrm{~cm}^{-1}$ ) and due to $\mathrm{C}-\mathrm{H}$ or $\mathrm{H}-\mathrm{C}=\mathrm{O}$ bonds, (1641.13 $\mathrm{cm}^{-1}$ and $\left.1635.34 \mathrm{~cm}^{-1}\right)$ due to $\mathrm{C}=0$ bonded, $\left(1455.03\right.$ and $\left.1445.39 \mathrm{~cm}^{-1}\right)$ due to $C=$ $\mathrm{N}$, and $\left(866.846 \mathrm{~cm}^{-1}\right.$ and $\left.884.202 \mathrm{~cm}^{-1}\right)$ due to $\mathrm{C}$. The authentic Mel recoded peaks at wave numbers (Figure 3c), 3285.14cm $\mathrm{cm}^{-1}, 2925 \mathrm{~cm}^{-1}$, $2850 \mathrm{~cm}^{-1}, 1724 \mathrm{~cm}^{-1}, 1631 \mathrm{~cm}^{-1}, 1455.99 \mathrm{~cm}^{-1}$, $896.737 \mathrm{~cm}^{-1}$ and $697.623 \mathrm{~cm}^{-1}$.

In vitro, the protective efficiency and tolerance under biosorption capacity of the tested strains against cadmium and lead ions.

\section{Determination of minimum inhibitory concentrations (MICs) of S. longisporoflavus NR043826 and $A$. niger MT355517 growth, Mel1 and Mel2 production against cadmium and lead ions stress}

The ability of microbes to tolerate and grow in the presence of $\mathrm{Cd}$ and $\mathrm{Pb}$ ions was evaluated by measuring the MICs of tested strains against $\mathrm{Cd}$ and $\mathrm{Pb}$ ions stress, and also to investigate the relation between the presence of melanin and its protection against $\mathrm{Cd}$ and $\mathrm{Pb}$ ions stress. The concentration of each metal solution added was gradually increased from (10-750 ppm) by increasing amounts of metal salts added to the media for $24 \mathrm{~h}$ at $37^{\circ} \mathrm{C}$, separately. The production of melanin and growth of all tested strains were decreased gradually by increasing the concentration of $\mathrm{Cd}$ or $\mathrm{pb}$ from $(10-750)$ $\mathrm{ppm}$. There is a significant negative relationship between different concentrations of cadmium and lead ions (ppm), melanin production, and dry weight of both tested strains was illustrated in (Figures 4 and 5).

The results revealed to the MICs of $S$. longisporoflavus NR043826 and Mel1 production was at $250 \mathrm{ppm}$. The MICs of $A$. niger MT355517 growth and Mel2 production was at $500 \mathrm{ppm}$ against lead acetate and cadmium chloride stress. The results detected in (Table2 and 3) demonstrated that $\mathrm{Pb}$ is more toxic than Cd. S. longisporoflavus NR043826 showed less resistance to $\mathrm{Cd}$ and $\mathrm{Pb}$ in comparison to A. niger MT355517 which can tolerate cadmium more than lead. Mel2 had a high degree of defence and protective action against the heavy metal stress.

\section{Transmission electron microscopy (TEM)} examination

Transmission electron microscopy micrographs of S. longisporoflavus NR043826 and A. niger MT355517 without, and with addition of lead were represented in Figures (6-8), Particles of lead were visible on the surface of the selected strain cells, whereas no $\mathrm{Pb}$ was visible on control micrographs. The TEM micrographs revealed the binding occurred on the surface of the microorganism cells whereas there was uptake or precipitation of $\mathrm{Pb}$ inside the melinized inner cell wall as shown in Figures (7a-9a) which treated with lead particles $(250,500 p p m)$. Figures (7b-9b) showed vacuolation and damages of the microorganism's cells which treated with lead particles (500 and 750ppm).

\section{DISCUSSION}

The molecular identification of Streptomyces sp revealed $99 \%$ similarity with other strains of Streptomyces sp accessed from GenBank to $S$. longisporoflavus NRRL ISP-5165 (Accession NO: NR043826). Almost similar results obtained by Coelho and Linhares (1993) who isolated melanogenic actinomycetes from soil. They found that $52 \%$ of pigment-producing colonies as possible Mel producers, which are primarily anaerobic, filamentous, Gram-positive, opportunistic bacteria that colonize human mucous membranes. 


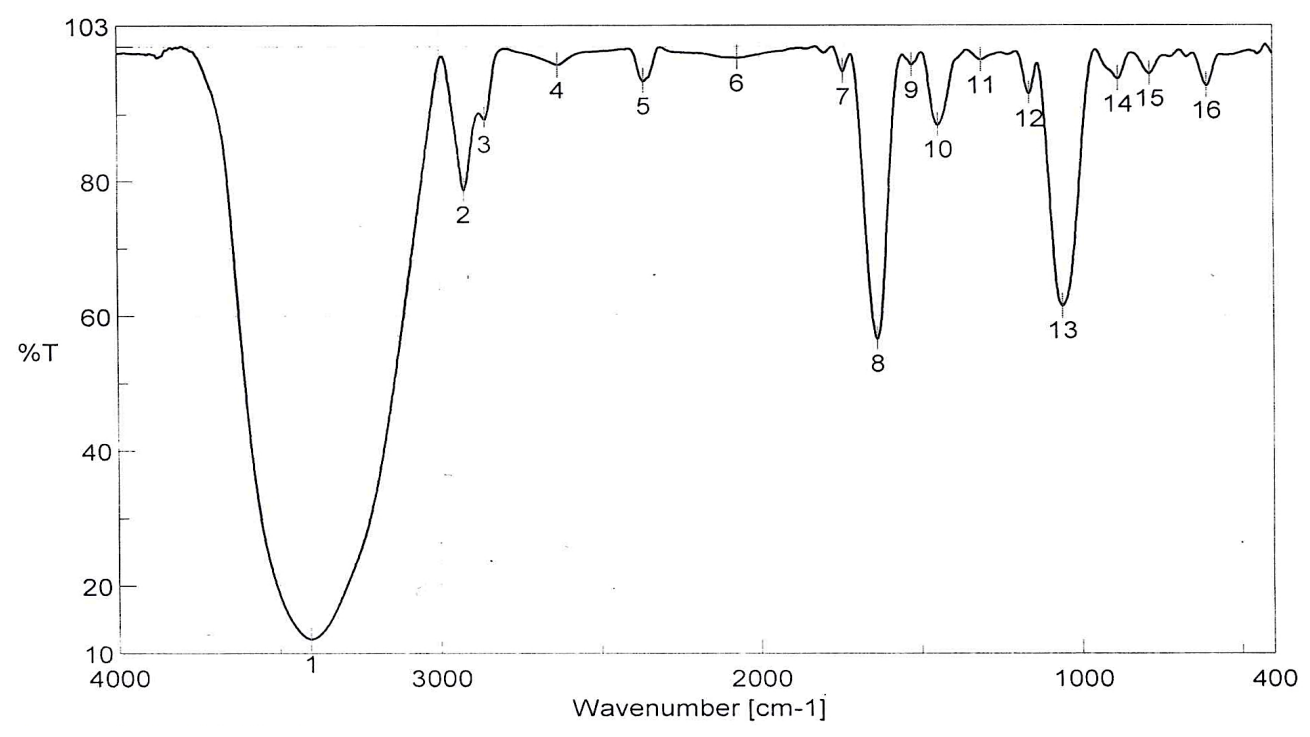

a)

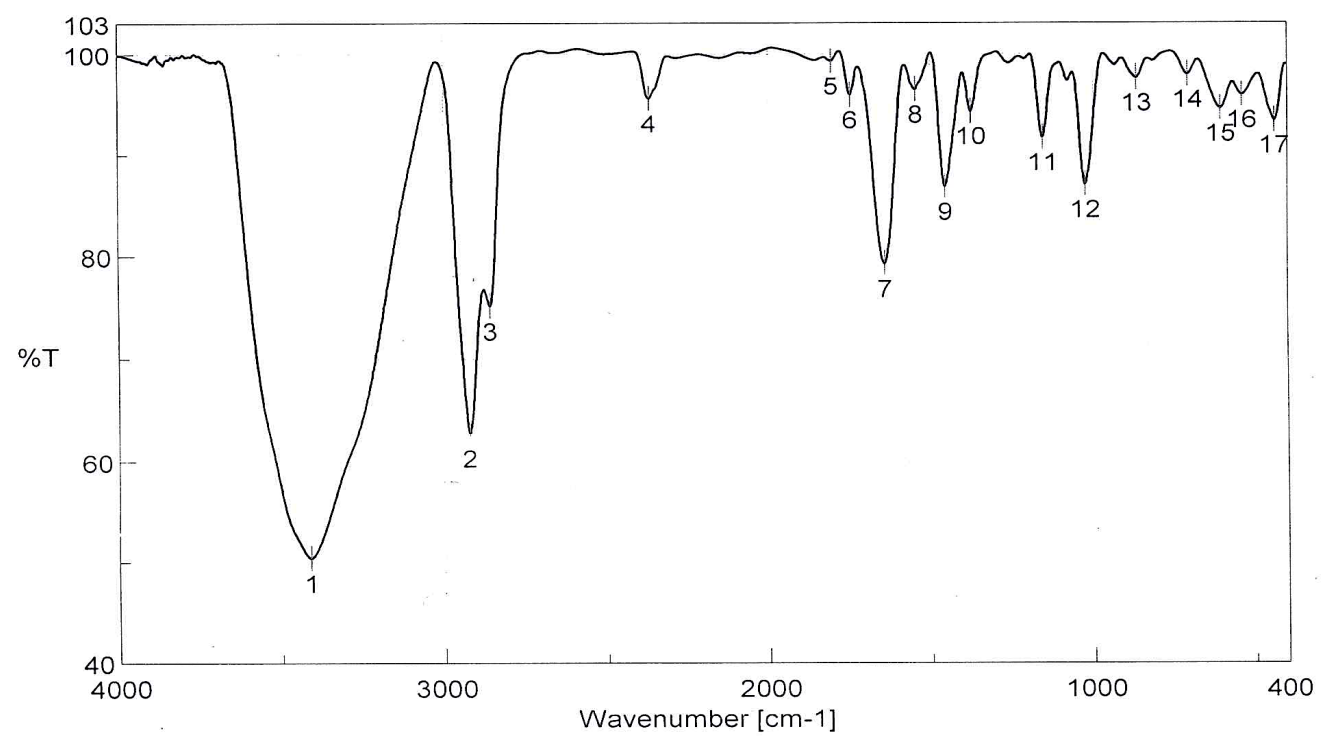

b)

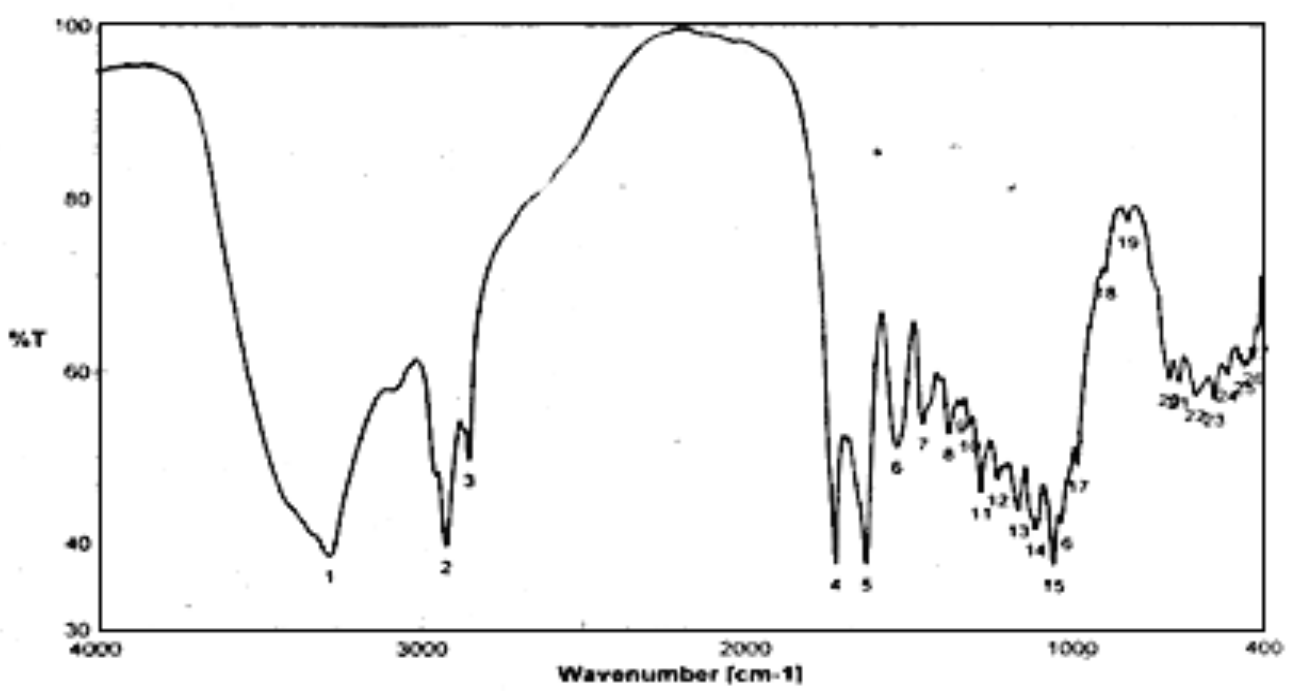

c)

Figure 3 The infra-red analysss of Mel1 (a), Mel2 (b) and standard Mel (c). 
There are over 40 currently recognized species of Streptomyces that are morphologically similar and resist identification by traditional phenotypic tests, fast partial sequencing of the 16S rRNA gene demonstrated complete molecular identity between our strain and other Streptomyces strains (Wong et al 2011), Aspergillus niger recorded the highest multi heavy metals resistance (Altschul et al., 1990) was identified and revealed $99.9 \%$ similarity with other strains of $A$. niger as accessed from GenBank (Accession NO: MT355517). Aspergillus niger is one of the Aspergillus genus' most common species and the bestcharacterized fungus-forming conidiospore. Henry et al., (2000) detected amplification fragments ranging from $565-613 \mathrm{bp}$ for different Aspergillus species, which was 595 bp in $A$. niger. In other fungal groups the ITS region was very useful in resolving taxonomic difficulties, as demonstrated by Driver et al., (2000) in the taxanomic revision of Inglis and reclassify entomopathogenic species of Aspergillus, previously misidentified by classical methods.

Mel1 of S. longisporoflavus NR043826 and Mel2 of $A$. niger MT355517 gave dark brown and black solutions, respectively. The two extracted Mel pigments were insoluble in water and organic solvents, were soluble completely after 2 hours in $\mathrm{KOH}$ at $100^{\circ} \mathrm{C}$, were decolorized by an oxidizing agent, were precipitated when their solutions were acidified by concentrated $\mathrm{HCl}$ to $\mathrm{pH} 2.2$, gave a positive reaction for polyphenols and produced flocculent brown precipitates with $\mathrm{FeC}_{3} 1 \%(\mathrm{w} / \mathrm{v})$. These results are almost similar to the results of Shrishailnath et al., (2010) who studied chemical characterization of the Mel pigment particles produced by Klebsiella sp. indicating that melanin pigment was acid resistant, alkali-soluble, insoluble in most of the organic solvents and water, got bleached when subjected to the action of oxidants as well as reductions, and was precipitated with ferric chloride and potassium ferricyanide. In our present study, the Infrared (IR) absorption spectra of the extracted Mel pigments were described in Figures $3 a$ and $3 b$ that revealed the absorption bands expected from aromatic compounds and their wave number as the same as the wavenumber of the standard Mel pigment.

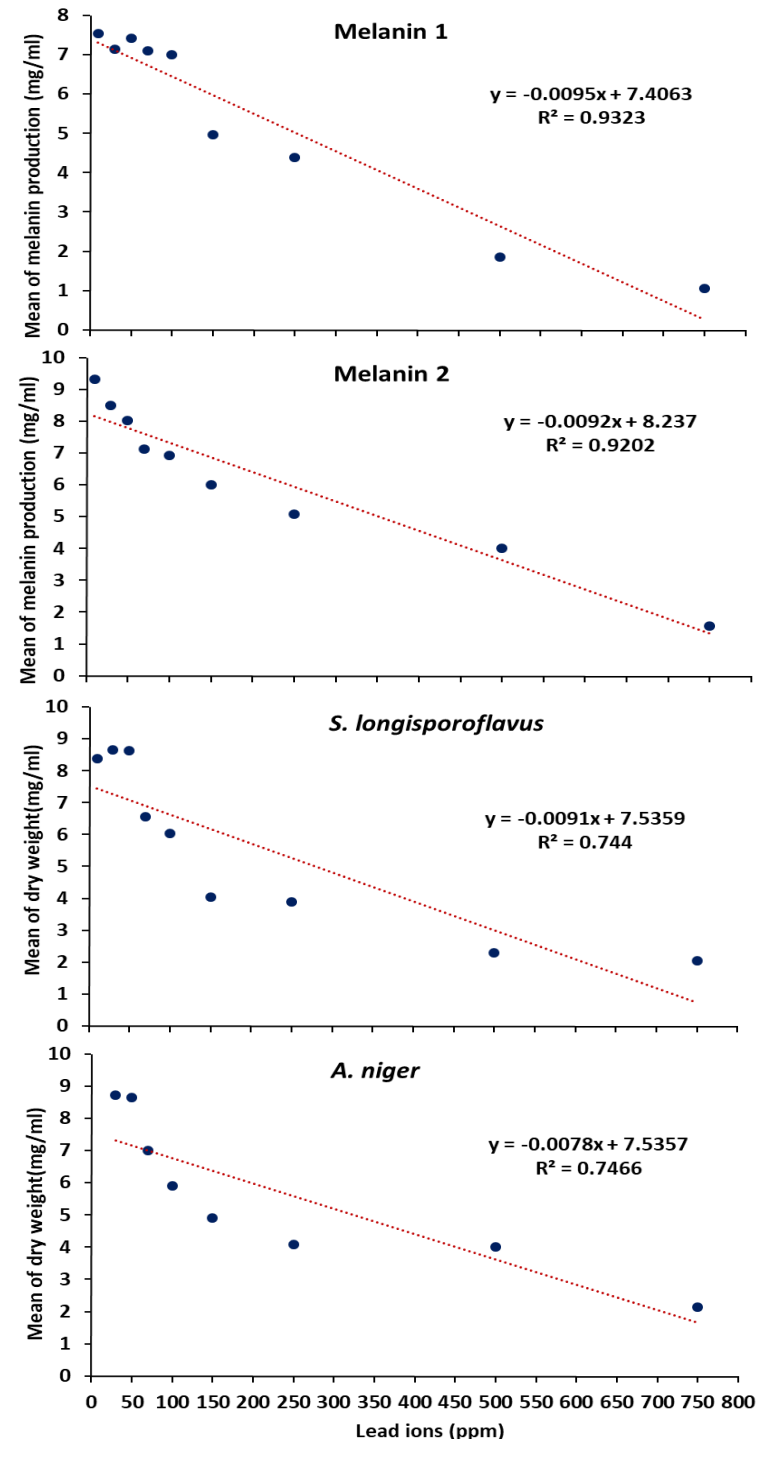

Figure 4. Regression analysis between different concentrations of $\mathrm{Pb}$ salts, Mel1, Mel2 production, $S$. longisporoflavus NR043826 and A. niger MT355517 growth.

These data were in consistent with the previous results provided by Bonner and Duncan (1962); Ellis and Griffiths (1974). The present study showed that S. longisporoflavus NR043826 and A. niger MT355517 were possible to tolerate, grow and producing melanin in the presence of $\mathrm{Cd}$ and $\mathrm{Pb}$ as detected in (Table 2 and 3), the production of melanin and growth of the microbial strains were decreased gradually by increasing the concentration of cadmium or lead; so, there is a significant negative relationship between different concentrations of cadmium and lead ions (ppm), reducing of melanin production, and dry weight of both tested strains was demonstrated in regression analysis (Figures 4 and 5). 


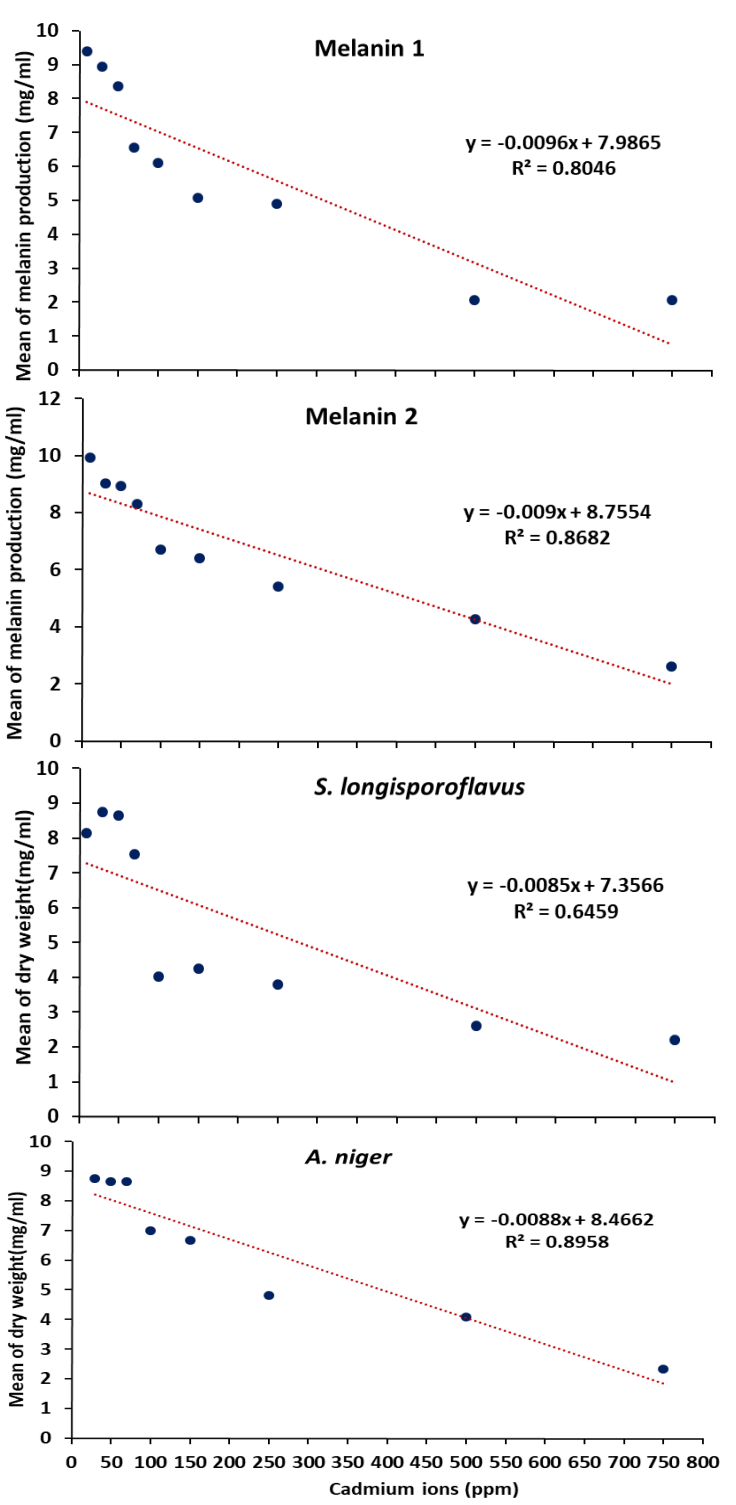

Figure 5. Regression analysis between different concentrations of Cd salts, Mel1, Mel2 production, $S$. longisporoflavus NR043826 and A. niger MT355517growth.

The MICs of S. longisporoflavus NR043826 growth and Mel1 production was at $250 \mathrm{ppm}$ and the MICs of $A$. niger MT355517 growth and Mel2 was at $500 \mathrm{ppm}$, against lead acetate $\mathrm{Pb}$ $\left(\mathrm{CH}_{3} \mathrm{CO}\right)_{2}$ and cadmium chloride $\left(\mathrm{CdCl}_{2}\right)$. According to the results investigated in (Table 2 and 3) it was clearly that $\mathrm{Pb}$ is more toxic than $\mathrm{Cd}$ and S. longisporoflavus NR043826 showed less resistance to cadmium and lead in comparison to A. niger MT355517, which can tolerate cadmium more than lead. Results indicated that Mel2 had a high degree of protectivity and defence in comparison to Mel1 against lead acetate and cadmium chloride stress.
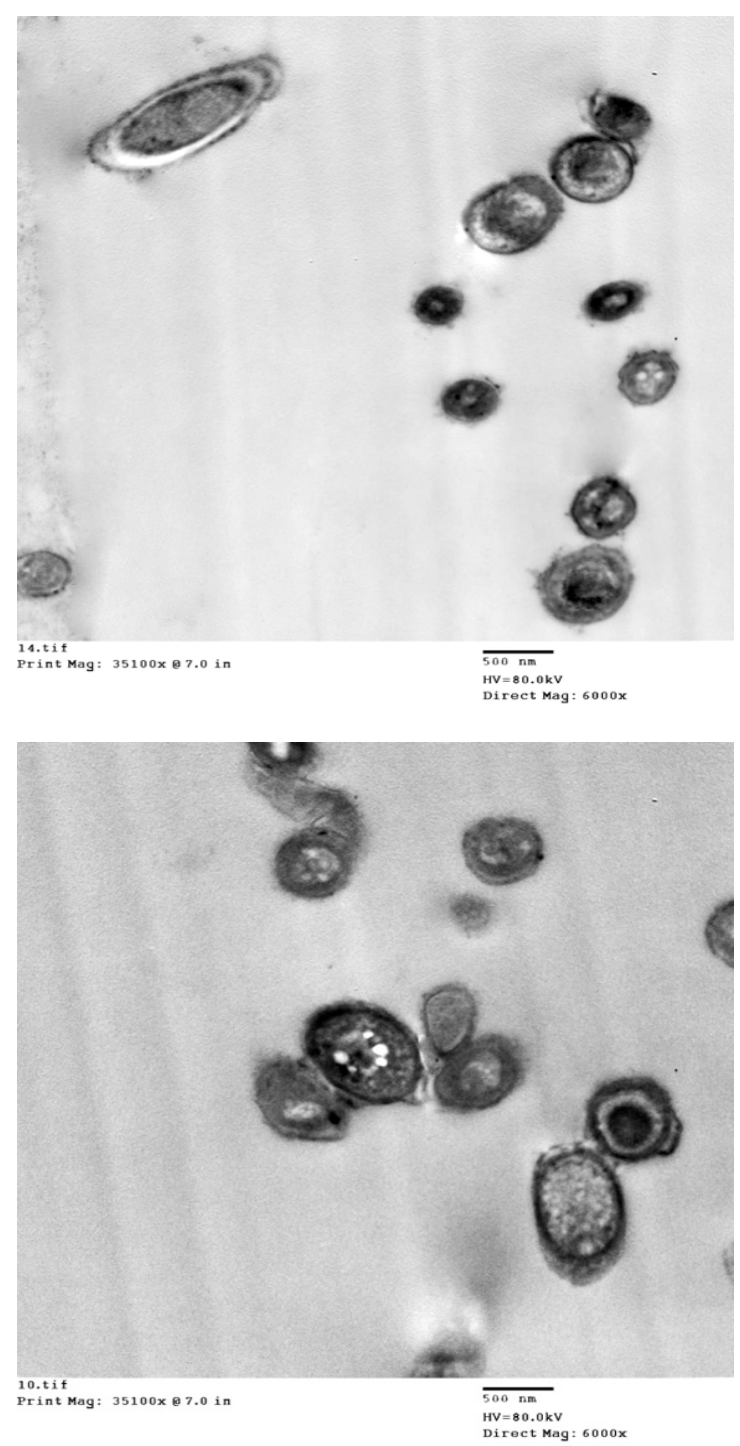

Figure 6. Transmission electron micrographs of $S$. longisporoflavus strain NR043826 without the addition of lead (control) Direct Magnification: 6000x and 8000x showed the cells have well-defined outer cell, dense inner cell walls and intact plasma cell membranes.

The obtained results were comparable to those of another study carried out by (Mamdouh et al., 2017) recorded novel fungal species that have tolerant potential to tolerate a high concentration of heavy metals especially, (Cd) and their potent efficacy to uptake it. The results showed a significant distribution of fungal isolates, as 64 fungal isolates were isolated at cadmium concentration of $100 \mathrm{ppm}$, and screened for further other high concentrations, $(200,300,400,500,600,700$, $800,900$ and $1000 \mathrm{ppm})$, results showed that the growth of fungal isolates recorded zero at $600 \mathrm{ppm}$ while at $400 \mathrm{ppm}$, growth was observed for 23 fungal isolates. 

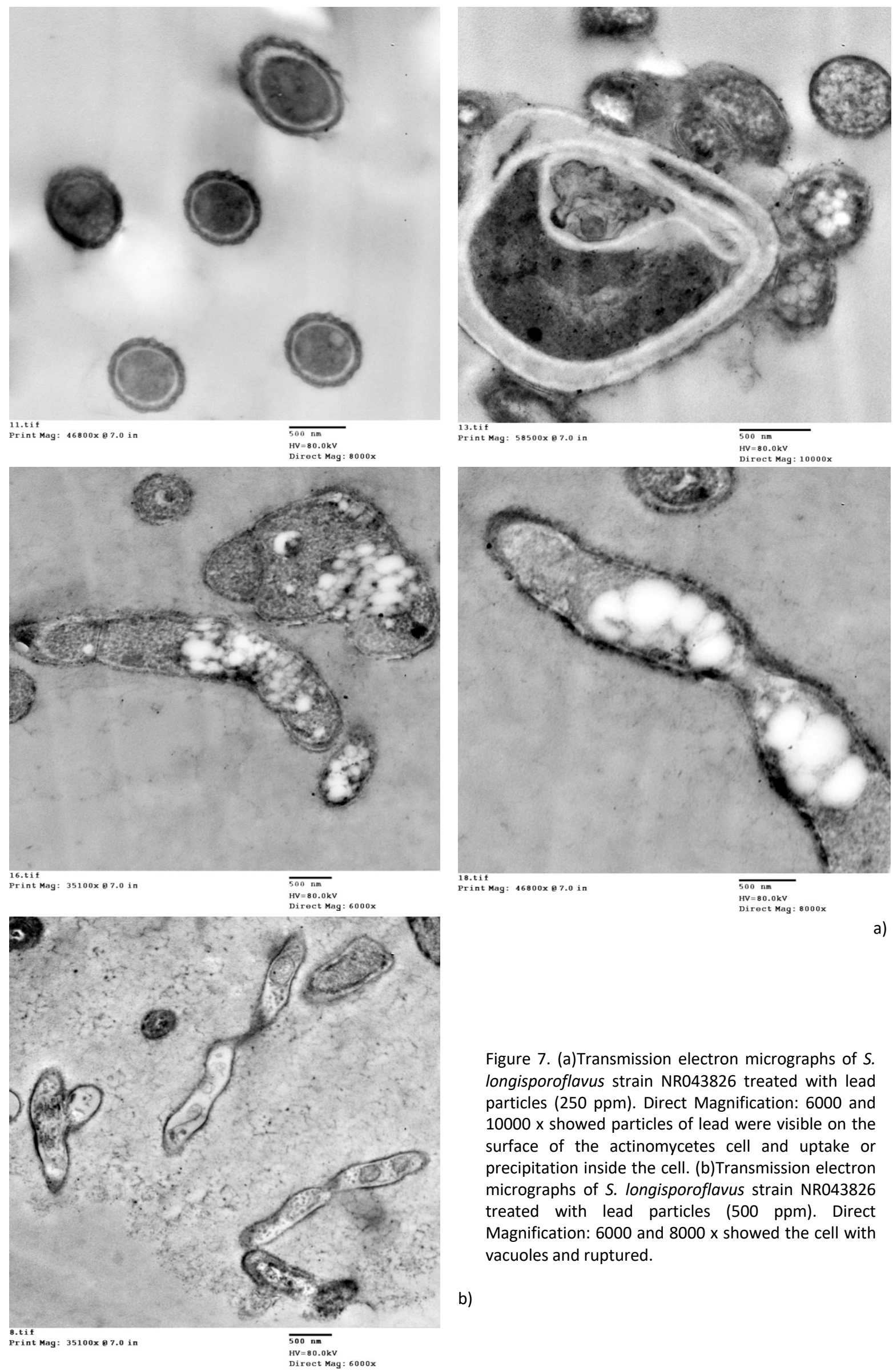

Figure 7. (a)Transmission electron micrographs of $S$. longisporoflavus strain NR043826 treated with lead particles (250 ppm). Direct Magnification: 6000 and $10000 \times$ showed particles of lead were visible on the surface of the actinomycetes cell and uptake or precipitation inside the cell. (b)Transmission electron micrographs of S. longisporoflavus strain NR043826 treated with lead particles $(500 \mathrm{ppm})$. Direct Magnification: 6000 and $8000 \times$ showed the cell with vacuoles and ruptured.

b) 

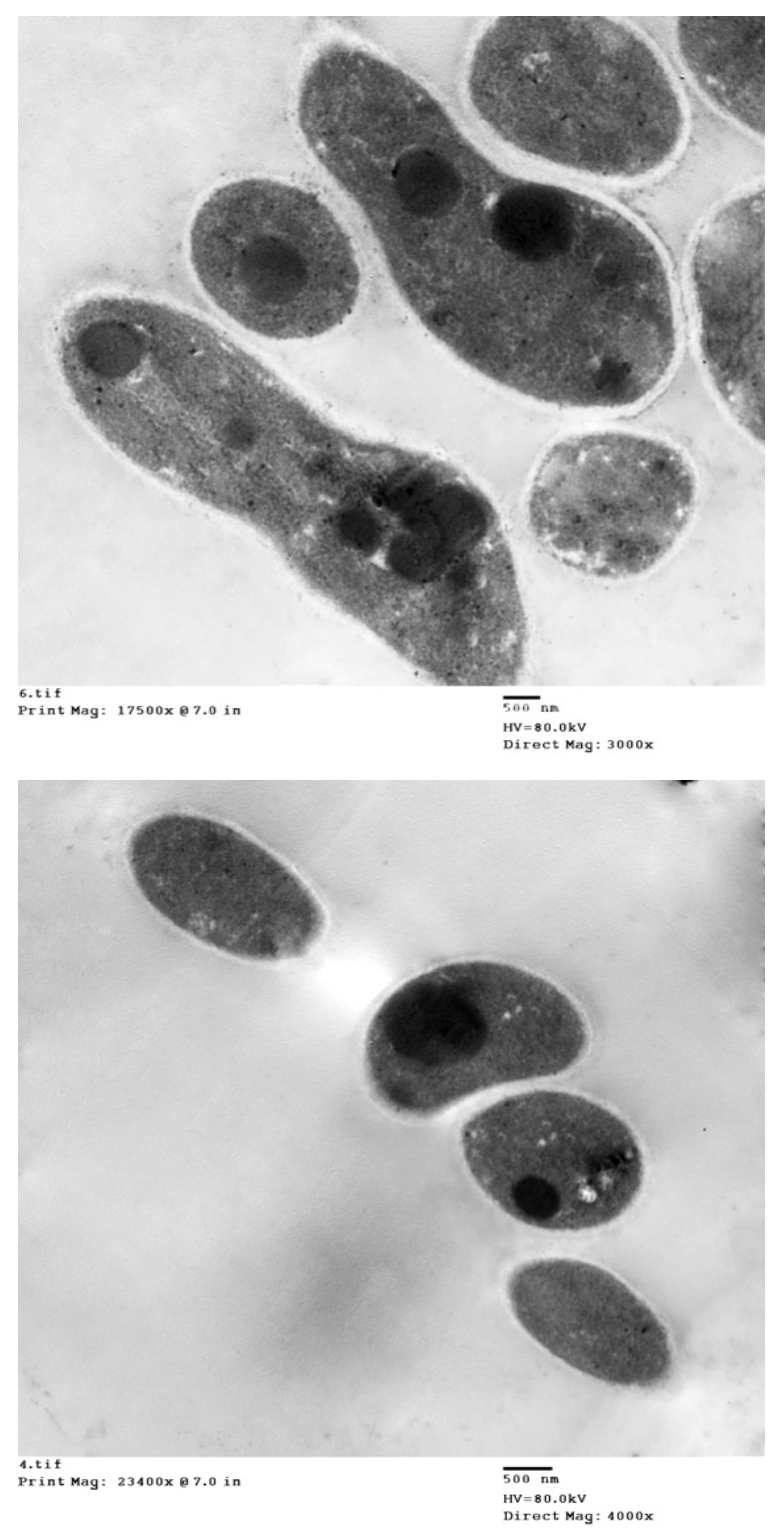

Figure 8. Transmission electron micrographs of $A$. niger strain MT355517 without the addition of lead (control). Direct Mag: 3000 and 4000x showed the cells have welldefined outer cell, dense inner cell walls and intact plasma cell membranes.

Amazingly, the minimum inhibitory concentration (MIC) was recorded using agar well method and the result showed that 5 fungal isolates were tolerated up to $480 \mathrm{ppm}$. By using macroscopic, microscopic and molecular techniques, the most potent fungal isolates were identified as $A$. niger. Natural melanin's metal ion chelating activity is used to eliminate heavy metals from the polluted water. We engineered marine bacterial melanin biosynthesis using various growth media, medium components and operating conditions (Harsha et al., 2018).
The growth behavior of Aspergillus awamori, Aspergillus flavus and Aspergillus niger with increasing heavy metals concentration was examined as tolerance index. The synergistic and inhibitory effect on the growth of both heavy metals with a lower and higher concentration. Our finding suggests that the resistant strains isolated from their polluted environment have greater relevance and application in bioremediation of heavy metals (Pawan, 2018).

Another study investigating, heavy metal ion tolerance that determined wastewater bacteria collected in Makkah City, Saudi Arabia for isolation (Alaa et al., 2016). Bacterial isolates were tolerant to cupper, cadmium, zinc and cobalt although the tolerance levels for the different concentrations of metal ions were unique for each isolate whereas Pseudomonas aeruginosa was shown in the presence of cupper $\approx 130 \mathrm{ppm}$, followed by zinc and cadmium $\approx 180$ and $200 \mathrm{ppm}$, respectively and finally to cobalt $\approx 220 \mathrm{ppm}$. Lactobacillus plantarum MF04201 had maximum uptake capacity of both $\mathrm{Cd}^{2+}$ and $\mathrm{Pb}^{2+}$ which was recorded at $\mathrm{pH} 2.0$ and a temperature of $22{ }^{\circ} \mathrm{C}$ after $1 \mathrm{hr}$, and exhibited a high degree of resistance up to 300 and $100 \mathrm{ppm}$; Furthermore, the results revealed that the use of L. plantarum MF042018 is an effective tool for the treatment of hazardous metal-polluted battery-manufacturing effluent (Ameen et al., 2020).

Saad et al., (2015), also isolated and purified 20 bacterial resistant strains in the respective of heavy metals from Helwan and 10th of Ramadan city areas and enriched in culture broth containing arsenic $(\mathrm{As})$, lead $(\mathrm{Pb})$, and cadmium (Cd) as As $\mathrm{HNa}_{2} \mathrm{O}_{4} \mathrm{H}_{2} \mathrm{O}, \mathrm{Pb}\left(\mathrm{NO}_{3}\right)_{2}$, and $\mathrm{CdSO}_{4}$, respectively. The growth parameters were optimized, and the maximum tolerable concentration of the respective bacterial strains growth was determined at 200,100, and 10 ppm against arsenic (As), lead (Pb), and cadmium (Cd) respectively.

The TEM micrographs of the selected strains shown in (Figures 7a, 7b, 9a, 9b) indicated that the binding of heavy metals occurred on the surface of the microbe's cells whereas there was 


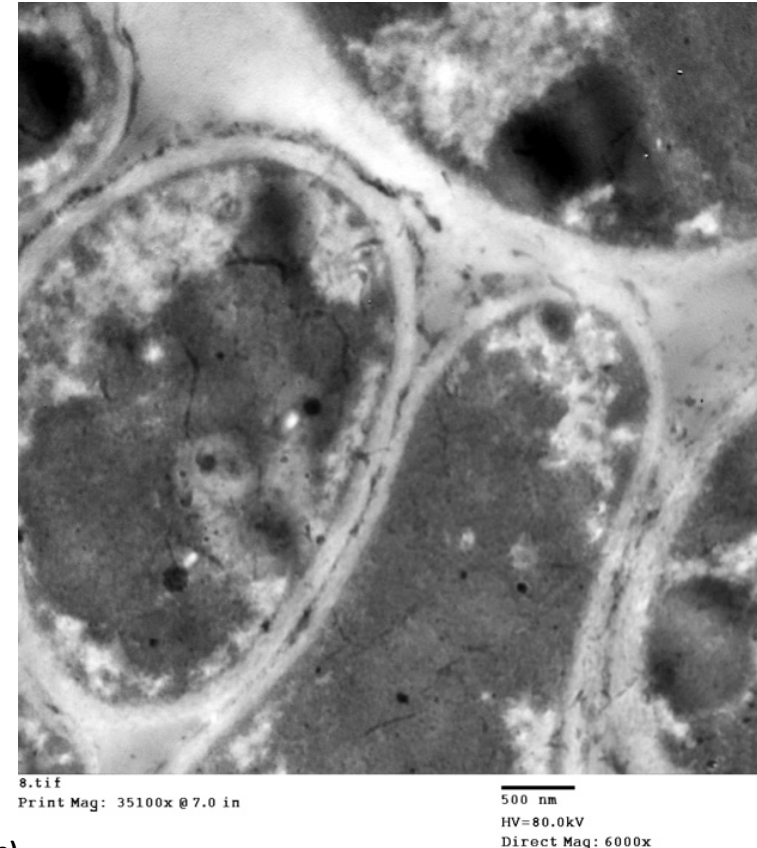

a)

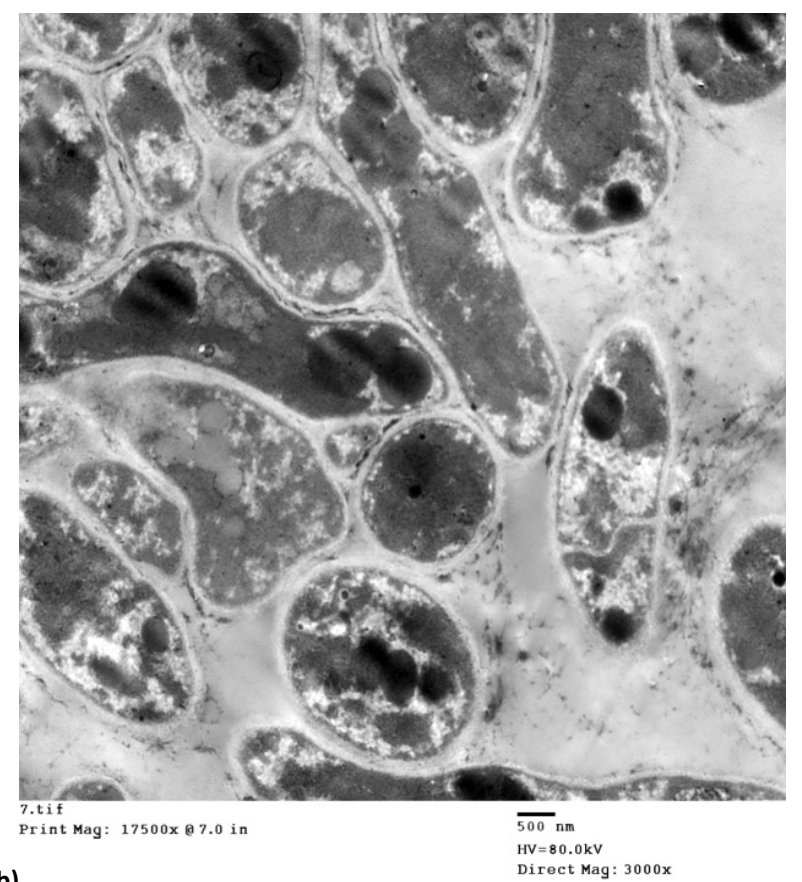

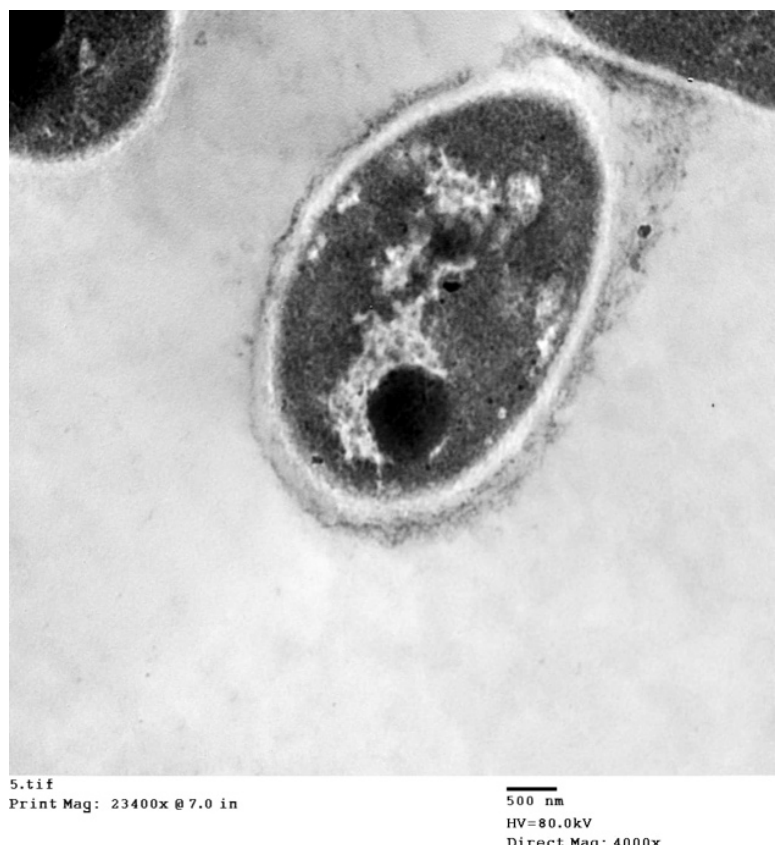

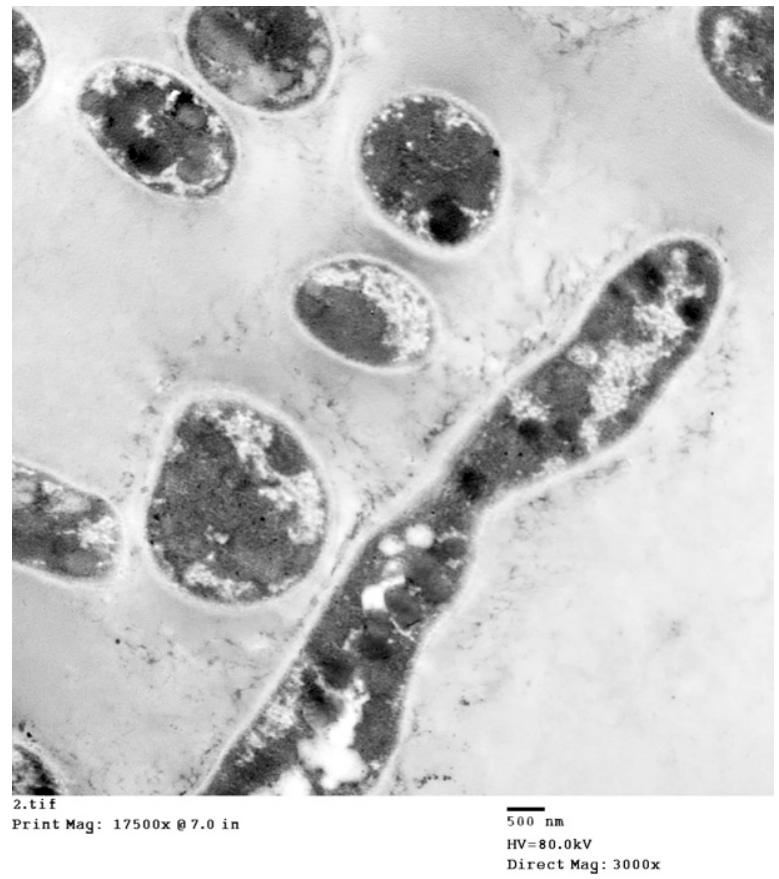

Figure 9. (a) Transmission electron micrographs of $A$. niger strain MT355517 treated with lead particles (500 ppm). Direct Mag: 3000 and $10000 \mathrm{x}$ showed particles of lead were visible on the surface of the fungus cell and uptake or precipitation inside the cell. (B) Transmission electron micrographs of $A$. niger strain MT355517 treated with lead particles (750 ppm). Direct Mag: $3000 \times$ showed the cell with vacuoles and ruptured

uptake or precipitation of $\mathrm{Pb}$ inside the melanized inner cell wall and finally microbial cells vacuolation and damage were appeared too. A. niger MT355517 cells showed less vacuolation and rupture in comparison to $S$. longisporoflavus NR043826 cells, Mel1 showed also less resistance and productivity against lead binding capacity. Cadmium was used in earlier experiments then lead was chosen in most experiments through binding capacity, because of $\mathrm{Pb}$ is more toxic than $\mathrm{Cd}$ and studies on $\mathrm{Cd}$ and $\mathrm{Pb}$ were often conducted together as the elements seem to react with microorganism's species in similar ways. The absorption of the metals from solution indicates cell surface binding, therefore TEM was 
performed on ultra-thin sections of $S$. thermophilus exposed to cadmium. TEM was preferable to scanning electron microscopy (SEM) as SEM was not able to determine if heavy metal particles were on the cell surface or in the interior of the cell (Monachese et al., 2012). On the same context, Chakravarty and Banerjee (2012) studied the mechanism of the cadmium binding on the cell wall of an acidophilic bacterium, TEM images of their study revealed the electron-dense region/layer throughout the cell wall only, with no intracellular accumulation. In contrast, other studies reported that $\mathrm{Cd}$ interaction with probiotic bacteria occurred through the binding on both the cell wall binding and intracellular accumulation.

\section{CONCLUSION}

Physocochemical characterizations of Mel1 and Mel2 were revealed insolubility in water, decolorization by an oxidizing agent, a positive reaction for polyphenols, and a similarity between their wave number of the absorption bands and the wave number of standard Mel pigment. S. longisporoflavus NR043826 showed less resistance against cadmium and lead ions in comparison to $A$. niger MT355517, which can tolerate cadmium more than lead. Also, Mel2 had a high degree of protective efficiency in comparison to Mel1 against lead acetate and cadmium chloride stress. A. niger MT355517 cells showed less vacuolation and rupture in comparison to S. longisporoflavus NR043826 cells under TEM examination..

\section{CONFLICTS OF INTEREST}

All authors declare no conflict of interest.

\section{FUNDING}

No fund was received for this work.

\section{REFERENCES}

Alaa, M. A. Assaeedi, A. Hussein, S. A. Abulreesh, H., and Gamal, O. (2016). Detection, Identification and Characterization of Some Heavy Metals Tolerant Bacteria. Agricultural Genetic Engineering Research Institute (AGERI), Egypt.

Ali, S., and Haq, I. (2010). Production of 3, 4dihydroxy L-phenylalanine by a newly isolated Aspergillus niger and parameter significance analysis by Plackett-Burman design. BMC Biotechnology 10, 86. https://doi.org/10.1186/1472-6750-10-86.

Altschul, S.F, Gish, W. Miller, W. Myers, E.W., and Lipman, D.J. (1990). Basic local alignment search tool. J. Mol. Biol., 215(3): 403-410.

Ameen, F.A., Hamdan, A.M., and El-Naggar, M.Y. (2020). Assessment of the heavy metal bioremediation efficiency of the novel marine lactic acid bacterium, Lactobacillus plantarum MF042018. Sci Rep 10, 314. https://doi.org/10.1038/s41598-019-57210-3.

Bonner, T.G., and Duncan, A. (1962). Infrared spectra of some melanins. Nature (Lond.), 194: 10781079.

Butler, M.J., and Day, A.W. (1998). Fungal melanins: a review. Canadian Journal of Microbiology, Vol. 44, No. 12: pp. 1115-1136.

Chakravarty, R., and Banerjee, P. (2012). Mechanism of cadmium binding on the cell wall of an acidophilic bacterium. Bioresour. Technol. 108, 176-183.

Chen, S. Xue, C. Wang, J. Feng, H. Wang, Y. Ma, Q., and Wang, D. (2009). Adsorption of $\mathrm{Pb}$ (II) and $\mathrm{Cd}$ (II) by Squid Ommastrephes bartrami Melanin. Bioinorg Chem Appl: 901563

Coelho, R.R., and Linhares, L.F. (1993). Melanogenic actinomycetes (Streptomyces spp.) from Brazilian soils. Biol. Fertil Soils. 15: 1-5.

Driver, F. Miliner, R.J., and Trueman, J.W.H. (2000). A taxonomic revision of Metarhizium based on a phyllogenetic analysis of rDNA sequence data. Mycol. Res., 104(2): 134-150.

Ellis, P. H., and Griffiths, D. A. (1974). The location and analysis of melanins in the cell walls of some soil fungi. Can. J. Microbiol, 20: 13791386.

Gadd, G.M., and deRome, L. (1988): Biosorption of copper by fungal melanin. Appl. Microbiol. Biotechnol, 29: 610-617.

Halttunen, T., Salminen, S., and Tahvonen, R. (2007). Rapid removal of lead and cadmium from water by specific lactic acid bacteria. Int. J. Food Microbiol. 114, 30-35.

Halttunen, T., Salminen, S., Meriluoto, J., Tahvonen, R., and Lertola, K. (2008). Reversible surface binding of cadmium and lead by lactic acid and bifidobacteria. Inter. J. Food Microbiol. 125, 170-175.

Hamilton, A. J. Gomez, B. L. (2002). Melanins in fungal pathogens. J. Med. Microbiol. 53 (3): 189-191.

Harsha, T. Keyur, R. Vishnu, M., and Raj, M.B. (2018). Melanin nano-pigments for heavy metal remediation from water. Pages 265-274.

Henry, T. Iwen, P.C., and Hinrichs, S. H. (2000). Idetification of Aspergillus species using internal transcribed spacer regions 1 and 2. J Clin Microbiol. 38:1510-1515. 
Herrera, J. Sistiaga, A. Vinther, J. Brown, C.M. Henderson D.M., and Summons, R.E. (2019). Molecular Characterization and Effect of Diagenesis and Maduration of Melanin in the Fossil Record. European Association of Geoscientists \& Engineers, Volume 2019, p.1-2.

Jin Ho Joo and Khalid, A. Hussein., (2012). Heavy Metal Tolerance of Fungi Isolated from Contaminated Soil. Korean Journal of Soil Science and Fertilizer 45 (4): 565-571.

Kaliyaraj, D., Rajendran, M., and Angamuthu, V. (2019). Bioleaching of heavy metals from printed circuit board (PCB) by Streptomyces albidoflavus TN10 isolated from insect nest. Bioresour. Bioprocess. 6, 47. https://doi.org/10.1186/s40643-019-0283-3

Kein, J. (2003). Melanins, metals, and mate quality Dept of Neurobiology and Behavior, Cornell Uni., Ithaca, NY 14853, USA OIKOS 102:2.

Komy, Z. Gabar, R. Shoriet, A., and Mohammed, R. (2006). Characterisation of acidic sites of Pseudomonas biomass capable of binding protons and cadmium and removal of cadmium via biosorption. World Journal of Microbiology and Biotechnology 22: 975-982.

Krysciak, J. (1985). Solubility of melanin and humic preparations in polar aromatic solvents. Folia Biol, 33: 195-214.

Lopusiewicz, L. (2018). Isolation, characterisation and biological activity of melanin from Exidianigricans. Center of Bioimmobilisation and Innovative Packaging Materials, Faculty of Food Sciences and Fisheries, West Pomeranian University of Technology Szczecin. World Scientific News 91:111-129.

Mamdouh, S. Elgamal, Ayma, F., and Salah, A. (2017). New report in cadmium tolerance by certain fungi isolated from Egyptian polluted soils. Egypt. J. Biotechnol. Vol. 55.

Manal, T. El sayed. (2019). Cadmium Biosorption from Wastewater by Yarrowia lipolytica AUMC 9256 Botany Department, Faculty of Science, Zagazig University, Zagazig, Egypt. Egypt. J. Bot. Vol. 59, No.1, pp. $151-169$.

Martinez, R.R. Wheeler, M.H. Plata, A.G. Rico, G., and Guerrero, H.T. (2000). Biosynthesis and functions of melanin in Sporothrix schenckii. Infect. Immun, 68: 3696- 3703.

Monachese, M. Burton, J., and Reid, G. (2012). Bioremediation and tolerance of humans to heavy metals through microbial processes: a potential role for probiotics? Applied and Environmental Microbiology, 78(18): 6397404.

Mrvcic, J. Stanzer, D. Bacun-Druzina, V., and StehlikTomas, V. (2009) Copper binding by lactic acid bacteria (LAB). Bioscience Microflora 28:1-6.
Murany, P. Wunderlich, J., and Franken, O. (2010). Aseptic packaging of food, basic principles and new developments concerning decontamination methods for packaging materials. In Innovation in Food Engineering: New Techniques and Products. (Edited by $\mathrm{M}$. Laura Passos and C. P. Ribeiro), pp. 437- 466. CRC Press, Boca Raton, FL.

Olaniran, O.A. Balgobind, A., and Pillay, B. (2013). Bioavailability of heavy metals in soil: impact on microbial biodegradation of organic compounds and possible improvement strategies. Int. J. Mol. Sci., 14 (5), pp. 1019710228.

Pardo, R. Herguedas, M. Barrado, E., and Vega, M. (2003). Biosorption of cadmium, copper, lead and zinc by inactive biomass of Pseudomonas putida. Analytical and Bioanalytical Chemistry 376: 26-32.

Pawan, K.R. (2018). Heavy metal tolerance and adaptability assessment of indigenous filamentous fungi isolated from industrial wastewater and sludge samples. Beni-Suef University Journal of Basic and Applied Sciences. Volume 7, Issue 4, Pages 688-694.

Penas, E. Martinez-Villaluenga, C. Frias, J. SanchezMartinez, M.J. Perez-Corona, M. T. Madrid, Y. Camara, C., and Vidal-Valverde, C. (2012). Se improves indole glucosinolate hydrolysis products content, Se-methylselenocysteine content, antioxidant capacityand potential anti-inflammatory properties of sauerkraut. Food Chemistry 132(2): 907-914.

Pihet, M. Vandeputte, P. Tronchin, G. Renier, G. Saulnier, P. Georgeault, S. Mallet, R. Chabasse, D. Symoens, F., and Bouchara, J.P. (2009). Melanin is an essential component for the integrity of the cell wall of Aspergillus fumigatus conidia. BMC Microbiol. 9:177.

Pointing, S. B., Bucher, V.V.C., and Vrijmoed, L.L.P. (2000).Dye decolorization by sub-tropical basidiomycetous fungi and the effect of metals on the decolorization ability. World J. Microbiol. Biotechnol, 16: 199-205.

Ravishankar, J.P. Muruganandam, V., and Suryanaryanan, T.S. (1995). Isolation and characterization of melanin from a marine fungus: Botanica Marina, 38: 413-416.

Roane, T.M., and Pepper, I.L. (2017). Microbial Remediation of soils co-cominated with cadmium. Department of Soil, Water and Environmental Science, the University of Arizona, Tucson, AZ 85721, (520)621-1647.

Rowely, B.I., and Pirt, S.J. (1972): Melanin production by Aspergillus nidulans in Batch and chemostat culture, Journal of Gen. Microbiol, 72: 553-563.

Saad, A. Moghannem, Bahgat, M. Refaat, Gamal, M. 
El-Sherbiny, Mohamed, H. El-Sayed, Islam, A. Elsehemy., and Mohamed, H. Kalaba (2015). Characterization of heavy metal and resistant bacteria isolated from polluted localities in Egypt. Department of Natural and Microbial Products Chemistry, Division of Pharmaceutical and Drug Industries Research, National Research Center, Cairo, Egypt, 14: 158-165.

SAS, (1985). SAS/ STAT User's Guide. SAS Instruction Incorporation, Cary. NC.

Sava, V.M. Galkin, B.N. Hong, M.Y. Yang, P.C., and Huang, G.S. (2001). A novel melanin-like pigment derived from black tea leaves with immuno-stimulating activity. Food Res Intern 34(4):337-343.

Sherborock-cox, V. Russell, N. J., and Gacesa, P. (1984). The purification and chemical characterization of alginate present in extracellular material produced by mucoid strains of Pseudomonas aeruginosa. Carbohydr. Res. 135(1): 147-154.

Shiguo, C. Changhu, X. Jingfeng, W. Hui, F. Yuming., and Wang, Q.M.(2009). Adsorption of $\mathrm{Pb}(\mathrm{II})$ and $\mathrm{Cd}(\mathrm{II})$ by Squid Ommastrephes bartrami Melanin. Bioinorg Chem Appl: 901563

Shirling, E. B., and Gottlieb, D. (1966). Methods for characterization of Streptomyces species. Int J Syst Bacteriol 16: 313-340.

Shrishailnath, S. Kulkarni, G. Yaligara, V. Kyoung, L., and Karegoudar, T.B.J. (2010). Purification and physicochemical characterization of melanin pigment from Klebsiella sp. Microbiol, Biotechnol., Department of Microbiology, Changwon National University, Korea, 20(11): 1513-1520.

Singh, V. Chaudhary, D.K., and Mani, I. (2012). Molecular characterization and modeling of secondary structure of 16S rRNA from Aeromonas veronii. Int. J. Appl. Biol. Pharm. Tech. 3(1): 253-260.
Suwannarach, N. Kumla, J. Watanabe, B. Matsui, K., and Lumyong, S. (2019). Characterization of melanin and optimal conditions for pigment production by an endophytic fungus, Spissiomyces endophytica SDBR-CMU319. PLoS ONE 14(9): e0222187.

Thomas, M. (1955). Melanins. (Paech, K. and Tracey. M. U., (eds) Modern Methods of plant analysis. 4 springer Verlag-Berlin, 661-675.

Vegliò, F., and Beolchini, F. (1997). Removal of metals by biosorption: a review. Hydrometallurgy 44: 301-316.

Volesky, B., and Schiewer, S. (1999). Biosorption of metals. In: FlickingerM, DrewSW, editors. Encyclopedia of Bioprocess Technology. New York:Wiley: 433-53.

Washington, J.A., and Sutter, V.L. (1980). Dilution susceptibility test: agar and macro-broth dilution procedures. In Manual of Clinical Microbiology, 3rd ed. Lennette E, Balows A, Hauler $W$ and Truant J. American Society of Microbiology 453458.

White, T.J, Bruns, T, Lee, S., and Taylor, J. (1990). Amplification and direct sequencing of fungal ribosomal RNA genes for phylogenetics. In:"PCR protocols: a guide to methods and applications. (Innis MA, Gelf and DH, SninskyJJ, White TJ. Eds)". New York: Acad. Press.pp. 315322.

Wong, V.K. Turmezei, T.D., and Weston, V.C. (2011). Actinomycosis. BMJ 343:d6099.10.113 6/bmj.

Zajac G. W. (1994). The fundamental unit of synthetic melanin: a verification by tunneling microscopy of X-ray scattering results. Biochem Biophys Acta 1199, 271-278.

Zhai, Q. Wang, G. Zhao, Liu, X. Tian, F. Zhang, H., and Chen, W. (2013). Protective effects of Lactobacillus plantarum CCFM8610 against acute. 



\section{Egyptian Association for Cancer Research (EACR)}

http://eacr.tanta.edu.eg/

EACR is an NGO society that was declared by the Ministry of Social Solidarity (Egypt) No. 1938 in 19/11/2014 based on the initiative of Prof. Mohamed Labib Salem, the current Chairman of EACR. EACR aims primarily to assist researchers, in particular young researchers in the field of cancer research through workshops, seminars and conferences. Its first international annual conference entitled "Anti-Cancer Drug Discovery" was successfully organized in April 2019 (http://acdd.tanta.edu.eg). Additionally, EACR aims to raise the awareness of the society about the importance of scientific research in the field of cancer research in prediction, early diagnosis and treatment of cancer. EACR is also keen to outreach the scientific community with periodicals and news on cancer research including peer-reviewed scientific journals for the publication of cutting-edge research. The official scientific journal of EACR is "International Journal of Cancer and biomedical Research (IJCBR: https://jcbr.journals.ekb.eg) was successfully issued in 2017 and has been sponsored by the Egyptian Knowledge Bank (EKB: www.ekb.eg).

\section{EACR Chairman,}

Prof. Mohamed Labib Salem, PhD

Professor of Immunology

Faculty of Science, Tanta Universiy, Egypt 


\section{GUIDE FOR AUTHORS}

Publisher :The International Journal of Cancer and Biomedical Research (IJCBR) is an International and interdisciplinary journal of preclinical and clinical studies in the area of cancer and biomedical research. It is a peer-reviewed journal in English, published quarterly (in March, June, September, and December) by the Egyptian Association for Cancer Research (EACR) in both print and online formats (4 issues making a volume). Special issues or supplements may also be produced from time to time upon agreement with the Editorial Board.

Scope :The main aim of IJCBR is to attract the best research in animal and human biology in health and diseases from across the spectrum of the biomedical sciences at the molecular, cellular, organ, and whole animal levels especially those that are related to cancer research, including causes, prediction, diagnosis, prognosis, and therapy.

Publication Fees :The journal does charge for submission, processing, or publication of manuscripts (2000 LE for Egyptians or $250 \$$ for non-Egyptians; EACR members receive 15\% discount on publication). Of them Peer-review fees (300 LE) should be paid on submission (non-refundable). For the fast-track production of the accepted manuscript, another 500 LE is paid.

General specifications for different types of article

- Submitted manuscripts should not have been published previously, except in a limited form (e.g. short communication to a symposium or as part of MSc or PhD theses) and should not be under consideration for publication by other journals.

- All co-authors should agree with the content of the manuscript. Authors must have obtained permission to use any copyrighted material in the manuscript before submission.

IJCBR publishes different types of articles

- Original Article (6000 words with $\mathbf{4}$ tables and $\mathbf{4}$ figures, maximum $\mathbf{8}$ display items): Articles with novel findings are the target of IJCBR. Articles presenting a detailed description of a new technique, comparison of existing methods, meta-analyses with comprehensive and in-depth discussion are considered. Papers in a numbered series are not accepted unless all are submitted at the same time.

- Short communications or case study (3000 words with $\mathbf{4}$ display items): Short communications present exceptionally exciting, novel or timely contents are considered. They will be peer-reviewed in the same way as research papers. The references are restricted to 15 .

- Reviews or systematic review (9000 words with $\mathbf{1 0}$ display items): They are invited by the Editorial Board or unsolicited. Review articles have to be contemporary and comprehensive and add information to the knowledge. Sharp critical analyses of novel data or concepts are encouraged. When relevant, a statistical analysis of data and a meta-analysis approach are recommended.

- Opinion papers, letter to the editor or comment to the editor (1500 words with $\mathbf{2}$ display items): They are submitted by invitation of the Editorial Board. They are short papers, which aim to inform scientists, industry, and the public and policymakers about cutting-edge issues in research or the impact of research. They reflect the opinion of their authors who bear full responsibility of the published paper. The references are restricted to 10 .

- Conference/Symposium papers: The journal will consider for publication the results of original work and critical reviews that are presented at conferences/symposia. Symposium organizers who wish to publish bundles of papers from a symposium/conference in IJCBR should first contact the Editor-in-Chief of the IJCBR (EACR@unv.tanta.edu.eg) for agreement. Supplementary material can be proposed and will be made available online. The responsibility for the preparation of a paper in a form suitable for publication lies with the author.

- Thesis: IJCBR can publish the summary and abstract of Master and PhD theses in a special issue.

English: Good quality of written English is required. Spelling may be in British or American English but must be consistent throughout the paper. Care should be exercised in the use of biological terminology that is ill-defined or of local familiarity only. We recommend that authors have their manuscripts checked by an English language native speaker before submission.

Manuscript layout: Manuscripts should be prepared using a standard word processing program and presented in a clear readable format with easily identified sections and headings. The manuscript layout is based on the following directions.

- The main text contains Title, Abstract, Keywords, Introduction, Material and Methods, Results, Discussion, References, Tables, figures.

- The title needs to be concise and informative. Use bold, with an initial capital for the first word only and for words that ordinarily take capitals.

- Short (running) title (max 80 characters including spacing).

- The article text should be typed with double line spacing with wide margins $(2.5 \mathrm{~cm})$.

- The lines must be continuously numbered; the pages must also be numbered.

- Font Calibri 12 should be used for the text, and 12 for the tables, figure legends and references.

- The sections should typically be assembled in the following order:

- Title page contains title, authors' names, full affiliations, acknowledgements and the corresponding author's contacts and Short title.

Abstract (max 250 words, single paragraph): The abstract should be complete and understandable without citation, references, table, or figure. Use structured abstract: Background, Aim, Materials \& Methods, Results and Conclusion. The context and the rationale of the study are presented succinctly to support the objectives. The experimental methods and main results are summarized but should not be overburdened by numerical values or probability values. The abstract ends with a short and clear conclusion. 
Keywords: Up to five short and specific keywords should complement the title with respect to indicating the subject of the paper in alphabetic order.

Introduction: The introduction briefly outlines the context of the work, presents the current issues that the authors are addressing and the rationale to support the objectives, and clearly defines the objectives.

Material and methods: Material and methods should be described in sufficient details so that others can repeat the experiment. Reference to previously published work may be used to give methodological details, provided that said publications are readily accessible and in English. The code of ethics should be followed for all experiments use animals or human samples.

Statistical analysis of results: The statistical design and the models of statistical analysis must be described, as well as each of the statistical methods used. Sufficient statistical details must be given to allow replication of the statistical analysis. The experimental unit should be defined (e.g., individual or group of animals).

Results: Data are presented as tables and figures. Brief description of the results for each table and figure should be presented. Unpublished data can be mentioned when necessary.

Discussion: Should be separate from the Results section and should focus only on intra- and inter-data discussion (the data in the results section) as well as with the relative data in the literature. Don't repeat information already presented in the Introduction section. Start the first paragraph in the Discussion with a paragraph stating the rationale behind the study, the objectives, and the main findings. End Discussion with a short conclusion.

Acknowledgements: In this section, the authors may acknowledge (briefly) their support staff.

Conflict of interest: All papers with a potential conflict of interest must include a description/explanation in a separate heading.

Funding details: The authors should state the source of findings of the study (with research funder and/or grant number). If no fund, the authors should state that the study is self-funded.

\section{References}

Citation of references: In the text, references should be cited by the author(s) surname(s) and the year of publication (e.g. Salem, 2020). References with two authors should be cited with both surnames (e.g. Salem and Meshrif, 2021). References with three or more authors should be cited with the first author followed by et al. (in italics; e.g. Salem et al., 2021). Names of organizations used as authors (e.g. Food and Drug Administration) should be written out in full in the list of references and on the first mention in the text. Subsequent mentions may be abbreviated (e.g. FDA).

- List of references. Literature cited should be listed in alphabetical order by authors' names. It is the author's responsibility to ensure that all references are correct. All authors should be written and so the full journal name.

- $\quad$ References from journal articles are formatted in APA as this example: Al-Amoudi WM (2018). Toxic effects of Lambdacyhalothrin on the rat thyroid. Involvement of oxidative stress and ameliorative effect of ginger extract. Toxicology Reports, 5: 728-736.

- $\quad$ References from books or official reports are formatted as this example. Kebreab E, Dijkstra ANM, Bannink A, Gerrits WJJ, \& France J (2006). Nutrient digestion and utilization in farm animals. CABI Publishing. Wallingford, UK.

- References from chapters or parts of books are formatted as this example. Nozière $P, \&$ Hoch $T$ (2006). Modelling fluxes of volatile fatty acids from rumen to portal blood. In: Nutrient digestion and utilization in farm animals (Kebreab E, Dijkstra ANM, Bannink A, Gerrits WJJ \& France J, eds.), pp. 40-47. CABI Publishing. Wallingford, UK.

Tables: The data should be presented in tables or in graphs, not both.

- Each table should be placed on a separate page at the end of the main text.

- Tables are numbered consecutively using Arabic numbering. They are referred to as Table 1 , Table 2, etc., with capital ' $T$ ', no italics

- $\quad$ Each table has its explanatory caption. The caption is sufficient to permit the table to be understood without reference to the text.

- Abbreviations used in tables/figures have to be defined either as footnotes or in the caption.

\section{Figures}

- $\quad$ Package the figures in a single PowerPoint file. Each figure in a separate slide.

- Figure size should be readable in a width of approximately 8-175 $\mathrm{mm}$ (i.e. the maximum size of printing over two columns).

- Ensure that the font size is large enough to be readable at the final print size, use Calibri font to ensure that they are consistent throughout the figures.

- $\quad$ The figures should preferably be provided as TIFF or EPS files.

- The resolutions of figures must be at least $300 \mathrm{dpi}$.

- Preparation of images for a manuscript: For guidance, we refer to the Journal of Cell Biology's instructions to authors (http://jcb.rupress.org/site/misc/ifora.xhtml\#image_aquisition).

- If a cropped image is included in the main text of a paper (e.g. a few lanes of a gel), display the full original image, including the appropriate controls, the molecular size ladder and/or the scale as relevant, as a single figure in a Supplementary Material file to facilitate peer-review and for subsequent online publication.

- Supplementary material is submitted along with the main manuscript in a separate file and identified at uploading as "Supplementary File - for Online Publication Only" The title of the article is included at the top of the supplementary material.

Corresponding author's guidelines: Upon acceptance the corresponding author is required to send his/her recent formal photo to be attached to the front page of the article. 


\title{
International Journal of Cancer \& Biomedical Research
}

(IJCBR) Online ISSN 2682-2628

\author{
Editor-in-Chief \\ Mohamed Labib Salem, PhD \\ Tanta University, Egypt
}

\begin{tabular}{l} 
EACR Board \\
\hline Nehal Elmashad, MD \\
Tanta University, Egypt \\
Nabil Mohy Eldin, PhD \\
Kafrelsheikh University, Egypt \\
Doaa Al-Ghareeb, PhD \\
Alexandria University, Egypt \\
Abdel-Aziz Zidan, PhD \\
Damanhour University, Egypt
\end{tabular}

\begin{tabular}{l} 
Managing Editor \\
\hline Wesam Meshrif, PhD \\
Tanta University, Egypt \\
Sohaila Galal, PhD \\
Tanta University, Egypt \\
Production and Contact \\
\hline Hamdi Kandil \\
Tanta University, Egypt \\
Email: ljcbr100@gmail.com
\end{tabular}

\section{Advisory Board}

Alberto Montero, MD

Taussig Cancer Center, Cleveland,

USA

Yi Zhang, MD

Zhengzhou University, China

Mark Robunstein, Ph D

Medical University of South

Carolina, USA

Mohsen Farid, Ph D

Derby University, USA

Natarajan Muthusamy, Ph D

Ohio State University, USA

Hideki Kasuya, MD

Nagoya University, Japan

Sherif El-Khamisy, Ph D

Sheffield University, UK

Mohamed Ghanem, Ph D

Kafr Elshikh University, Egypt

Sayed Bakry, Ph D

Alazhar University, Egypt

Sameh Ali, Ph D

Nationa Liver Institute, Egypt

Gamal Badr, Ph D

Assuit University, Egypt

Nadia Hamdy, Pharm D

Ain Shams University, Egypt

\section{Editorial Board}

\section{Clinical studies}

Hesham Tawfik, MD

Tanta University, Egypt

Mohamed Attia, MD

Tanta University, Egypt

Mohamed Elshanshory, MD

Tanta University, Egypt

Essam Elshiekh, MD

Tanta Cancer Center, Egypt

Rasha Eraky, MD

Tanta University, Egypt

Shaima Abou-Kjatwa, MD

Tanta University, Egypt

Marcela Diaz, MD

Cleveland Clinic Foundation, USA

Mohamed Abou-El-Enein, MD

Charité Universitätsmedizin Berlin,

Germany
Alaa Eldin Almostafa, MD

McGill University, Canada

Olfat Gadallah, MD

Tanta University, Egypt

Nagla Sarhan, MD

Tanta University, Egypt

Naglaa Fathy, Pharm D

Zagazik University, Egypt

Mohamed Salama, MD

Mansoura University, Egypt

Mona Marie, MD

Alexandria University, Egypt

Preclinical studies

Mostafa El-Sheekh

Tanta University, Egypt

El-Refai Kenawy, Ph D

Tanta University, Egypt

Mohamed Noureldin, Ph D

Banaha University, Egypt

Yousry Albolkiny, Ph D

Tanta University, Egypt

Elsayed Salim, Ph D

Tanta University, Egypt

Shengdian Wang, Ph D

Chinese Academy of Sciences,

China

Sabry El Naggar, Ph D

Tnata Univesity, Egypr

Faris Alenzi, Ph D

Prince Sattam bin Abdulaziz

University, KSA

Ibrahim El-Sayed, Ph D

Menoufia University, Egypt

Tarek Aboul-Fadl, Ph D

Assiut University, Egypt

Rabab Khairat, Ph D

National Research Center,

Giza, Egypt

Wael Lotfy, Ph D

Alexandria University, Egypt

Ashraf Tabll, Ph D

National Research Center, Egypt

Nahla Shoukry, Ph D

Suez University, Egypt
Medhat Eldenary, Ph D

Tanta University, Egypt

Azza Hasan, Ph D

Menufia University, Egypt

Nanees Gamal Eldin, Ph D

Tanta University, Egypt

Mohamed Mansour, UK

Sabbah Hammoury, Ph D

Alexandria Ayadi Almostaqba

Oncology Hospital, Egypt

Nehal Aboulfotoh, Ph D

Zewail City for Science and

Technology, Cairo, Egypt

Amir Elkhami, Ph D

Galaxo, San Francisco, USA

Ahmed Alzohairy, Ph D

Zagazi University, Egypt

Wgady Khalil, Ph D

National Research Center, Egypt

Amr Amin, Ph D

United Arab Emirates

University, UAE

AbdelRahman Zekri, Ph D

National Cancer Institute, Egypt

Hussein Khamis, Ph D

Alexandria University, Egypt

Magdy Mahfouz, Ph D

Kafr Elsheikh University, Egypt

Ehab Elbedewey, Ph D

Tanta University, Egypt

Abeer Badr, Ph D

Cairo University, Egypt

Mamdooh Ghoneum, Ph D

Charles Drew University of

Medicine \& Science, USA

Haiam Abou Elela, Ph D

National Institute of Oceanography and Fisherie, Egypt

Maha EL-Demellawi, Ph D City for Scientific Research \&

Technology Applications, Egypt

Desouky Abd-El-Haleem, Ph D

City for Scientific Research \&

Technology Applications, Egypt 